\title{
Az Információs Társadalomban megjelenő tanulmányok topikelemzése
}

\author{
Boldog születésnapot, Információs Társadalom!
}

A tanulmány dedikáltan az Információs Társadalom folyóirat jubileumi számába készült, elsődleges célja, hogy áttekintse a folyóirat elmúlt éveinek publikációit és szerzői hálózatát. A tanulmány szerzői azt vizsgálják, hogy az Információs Társadalom folyóirat milyen témákat emelt be az „information society studies” hazai diskurzusába az elmúlt 15 évben.

A cikk szerzői természetesnyelv-feldolgozással (Natural Language Processing, NLP), azon belül is topikmodellezéssel elemzik a folyóiratban 2005-től megjelent tanulmányokat, hogy feltárják a folyóirat tematikus szerkezetét. Az elemzés során 10 topikot, vagyis látens témát különítenek el, például a hálózatok/rendszerek, az oktatás, az adatvédelem és az internet és közösségek területét azonosítva a Látens Dirichlet Allokáció (LDA) eljárás segítségével. A tartalmi elemzés mellett a cikk betekintést nyújt a folyóiratba publikálók társzszerzőségi hálózatába, valamint a szerzők és az egyes topikok kapcsolatába is. A társszerzőség szerinti hálózatban három, viszonylag sok szerzőt tartalmazó algráf azonosítható, de a hálózat alapját jellemzően diádok, triádok és négyes csoportok alkotják. A szerzők cikkeinek topikhovatartozása azt mutatja, hogy a sokat publikáló szerzők cikkei jellemzően 3-4 topikba kerülnek.

Kulcsszavak: Információs Társadalom, topikmodell, természetesnyelv-feldolgozás, szövegelemzés, hálózatelemzés

\section{Szerzői információ}

Katona Eszter, ELTE Társadalomtudományi Kar, RC2S2

https://orcid.org/0000-0001-9096-6017

Knap Árpád, ELTE Társadalomtudományi Kar, RC2S2

https://orcid.org/0000-0002-4290-6025

Máté Fanni, ELTE Társadalomtudományi Kar, RC2S2

https://orcid.org/0000-0002-2032-776X

Csótó Mihály, Chelonian Bt. https://orcid.org/0000-0002-9260-8739

Így hivatkozzon erre a cikkre:

Máté Fanni, Katona Eszter, Knap Árpád, Csótó Mihály. „Az Információs Társadalomban megjelenő tanulmányok topikelemzése”. Információs Társadalom XXI, 1. szám (2021): 10-47.

$=$ https://dx.doi.org/10.22503/inftars.XXI.2021.1.1

A folyóiratban közölt müvek

a Creative Commons Nevezd meg! - Ne add el! - Így add tovább! 4.0

Nemzetközi Licenc feltételeinek megfelelöen használhatók. 


\section{Topic modelling of the Információs Társadalom}

\section{Happy Birthday, Információs Társadalom!}

The study was written for the jubilee issue of the Információs Társadalom (Information Society) journal, with the primary aim of reviewing the journal's publications and the journal's author network in the last 15 years. The authors of the study examine what topics were included in the Hungarian discourse of "information society studies" by the journal. The authors of the article use Natural Language Processing (NLP), to be precise, topic modeling, to analyze the thematic structure of the journal. The analysis identifies 10 latent topics, i.e. networks / systems, education, data protection, Internet and communities using the Latent Dirichlet Allocation (LDA). In addition to content analysis, the article also provides insight into the co-author network of the journal, as well as the relationship between authors and topics. The network is typically based on dyads, triads, and groups of four authors. Three graphs were identified with a high number of authors in the whole network. Based on the topic model it seems that those authors' articles who published a lot in the journal, belong to 3-4 topics.

Keywords: Information Society, Natural Language Processing, topic modeling, text analysis, network analysis 


\section{Bevezető}

Az Információs Társadalom első megjelenésétől kezdve megannyi szerző számtalan tanulmánnyal, konferenciabeszámolóval vagy klasszikus művek fordításával járult hozzá a szociológia információs társadalommal foglalkozó területének meghonosításához. Tanulmányunk célja, hogy kihasználva a természetesnyelv-feldolgozás és a hálózatelemzés adta eszközöket, bemutassuk, milyen témák köré csoportosíthatók a folyóiratban megjelent cikkek, és kik járultak hozzá a terület hazai diskurzusához a folyóirat lapjain keresztül. Ezzel átnézetes képet adva arról, hogy egy, a tématerület jelenségeinek feldolgozását hazánkban elsőként felvállaló, központi orgánumában milyen témák jelennek meg, s azok miként változnak az időben.

A folyóirat 2001-ben alakult azzal az igénnyel, hogy a fejlődő, de a nemzetközi folyamatoktól elmaradó, információs társadalommal foglalkozó hazai tudományos élet felzárkózását elősegítse (ahogy az első lapszám szerkesztőségi beköszöntője fogalmaz, „a döntés előkészítés és a közvélemény-formálás terepeit meghatározó szakmai kör (felsőoktatás, kutatók, pedagógusok, vezető köztisztviselők, vállalatvezetők, a médiaértelmiség) reprezentatív fórummal rendelkezzen, ahol egyszerre tájékozódhat, vitatkozhat, és kaphat a felszínes sajtókommentároknál mélyebb elemzést az információs korszak jelenségeiröl”). Ennek érdekében a szaklap tudományos alapokra épülő tájékoztatást nyújt a téma iránt érdeklődőknek és publikálási lehetőséget biztosít a területtel foglalkozó kutatók számára.

Az Információs Társadalom alapvetően a Budapesti Műszaki Egyetemen, a kilencvenes évek végén alakult kutatóintézet, az Információs Társadalom- és Trendkutató Központ (ITTK), illetve annak tágan vett holdudvara köré szerveződött, az intézet 2010-es évek elején történt megszűnéséig. A folyóirat a kezdetektől az INFONIA Alapítvány gondozásában jelenik meg (2005-től 2020-ig a Gondolat Kiadóval partnerségben), a közelmúltban ismét szorosabbra füzve kapcsolatát a Budapesti Műszaki Egyetemmel, a Gazdasági és Társadalomtudományi Karának támogatása révén. A lap jelenlegi főszerkesztője Héder Mihály, a szerkesztőbizottság elnöke Nyíri Kristóf. ${ }^{1}$

Kutatásunkban a korábbi számok nehéz feldolgozhatósága miatt a folyóirat 2005-től 2020-ig megjelenő lapszámaiban található írások elemzését tudtuk elvégezni. ${ }^{2}$ Tanulmányunkban először az alkalmazott szövegelemzési

\footnotetext{
${ }^{1}$ A folyóiratot Z. Karvalics László alapította, s ő volt az első főszerkesztő is a 2005. évi 2. számig, amikor Pintér Róbert vette át tőle ezt a pozíciót. Őt követte Molnár Szilárd és Rab Árpád 2009-től. 2012-ben csatlakozott Csótó Mihály a főszerkesztőpároshoz, akikkel három éven keresztül vezették a lapot. 2015-től Rab Árpád és Csótó Mihály, majd 2016-tól Csótó Mihály maradt a lap főszerkesztője. Őt a jelenlegi fószerkesztő, Héder Mihály követte a 19. évfolyam 2. számától, 2019-től. A szerkesztőbizottság létszáma a kezdeti 3-4 főről az első években folyamatosan gyarapodott, majd megállapodott egy körülbelül 12-15 fős létszámon, melynek magja gyakorlatilag állandónak tekinthető.

2 Az első feldolgozott lapszám a 2005. évi 2. szám, az utolsó pedig a 2020. évi 1. szám volt. Ennek megfelelően a folyóirat első 12 száma (2001. évi 1. számtól a 2005. évi 1. számig) maradt ki elem-
} 
módszert mutatjuk be, majd a folyóirat szövegeinek a modellezéshez történő előkészítését írjuk le, annak érdekében, hogy felfedjük az eredmények mögött rejlő apparátust. Ezt követően bemutatjuk a topikmodellezés eredményét, a 10 azonosított tematikus csoportot és azok jellemzőit, illetve röviden írunk arról, hogy a több tanulmányt is publikáló szerzők cikkei inkább egy topikhoz tartoznak-e vagy több tématerületen jelennek meg. Cikkünk végén a folyóiratba publikáló szerzők társszerzőségi hálózatát mutatjuk be, hogy képet kapjunk arról, milyen szerzőségi kapcsolatokat rajzolnak ki az Információs Társadalom cikkei.

\section{Módszertan}

A folyóirat archívumának feldolgozása hagyományos tartalomelemzéssel nehézkes és kifejezetten időigényes lenne. A gépi tanulás, azon belül is a természetesnyelv-feldolgozás (Natural Language Processing, NLP) lehetővé teszi számunkra, hogy a humán kapacitást meghaladó mennyiségű szöveget elemezzünk. Az NLP feladata ugyanis a természetesen előforduló (beszélt és írott) nyelvek számítástudományi módszerekkel történő feldolgozását végzi többféle alkalmazási terület számára oly módon, hogy az az emberi feldolgozáshoz hasonló minőségű legyen (Liddy 2019). Ennek egyik módszere a topikmodellezés.

Az általunk használt Látens Dirichlet Allokáció (LDA) egy nem felügyelt ${ }^{3}$ topikmodellezési eljárás, amellyel nagy méretű szövegkorpuszok dolgozhatók fel. Az eljárás célja, hogy feltárja a korpusz látens tematikus struktúráját olyan módon, hogy topikokat hoz létre. A topikok létrehozásához a szavak együttes előfordulását elemzi, és abból a feltevésből indul ki, hogy a topikok jellemezhetőek a hozzájuk tartozó szavak segítségével, azaz a hasonló témájú dokumentumok hasonló szókészletet használnak. Emiatt tehát azt mondhatjuk, hogy egy olyan dokumentum, ami egy bizonyos topikhoz tartozik, nagyobb eséllyel tartalmazza a topikra jellemző szavakat. Az LDA-modell a dokumentumokat véges számú topik keverékeként kezeli (Blei, Ng, és Jordan 2003; Blei és Lafferty 2009; Németh, Katona, és Kmetty 2020; Németh és Koltai 2020), a topikhoz tartozás pedig egy valószínűségértékként jelenik meg. Elemzésünkben minden dokumentumot ahhoz a topikhoz rendeltük, amelyik a legdominánsabban jelent meg az adott dokumentumban, a kvalitatív feldolgozás során pedig különös figyelmet fordítottunk azokra a szövegekre,

zésünkből. Ezek a lapszámok csak olyan formátumban álltak a rendelkezésünkre, amelyet nem tudtunk automatizált módon megfelelő minőségü digitális szöveggé alakítani.

${ }^{3}$ A modellalkotás során megkülönböztetünk felügyelt (supervised) és nem felügyelt (unsupervised) módszereket. Nem felügyelt esetben nem rendelkezünk előzetes ismeretekkel az egyes elemek csoporthovatartozásáról, a modell segítségével korábban nem ismert, látens struktúrákat keresünk. 
amelyek nagy valószínüséggel tartoztak az adott topikhoz, tehát a legnagyobb mértékben reprezentálták azt.

\section{Adattisztítás és előfeldolgozás}

Ahhoz, hogy az általunk alkalmazott topikmodellezési eljárás megfelelő teljesítményt nyújtson és interpretálható eredménnyel szolgáljon, számos tisztítási lépés végrehajtása szükséges a nyers adatokon. Ezeket a lépéseket a következőkben ismertetjük.

A lapszámokhoz szkennelt, OCR-réteg ${ }^{4}$ nélküli PDF-állományokban jutottunk hozzá. A PDF-fájlokat optikai karakterfelismeréssel alakítottuk át digitális szöveggé. Először az elemzésbe bevont 56 lapszámot manuálisan, szövegszerkesztő segítségével szabadítottuk meg a fej- és láblécektől, címlapoktól, lábjegyzetektől, ábráktól, grafikonoktól, táblázatoktól és képektől, töröltük továbbá az oldalszámokat, a tartalomjegyzékeket és a cikkek végén szereplő irodalomjegyzékeket. Az volt a célunk, hogy kizárólag a nyers szöveg maradjon meg, mivel ezeket tudjuk felhasználni a modellekhez. A felsorolt többi adat zajként jelent volna meg az elemzésben. A tisztítási folyamat során szintén eltávolítottuk a nem magyar nyelvü szövegeket (ezek praktikusan a lapban megjelent tanulmányok angol nyelvü absztraktjai), az ismétlődő, rövid szövegrészeket (mint például a cikkek végén szereplő, egyes szerzőket bemutató rövid életrajzokat, mini CV-ket), a Szemle rovat tartalmát (mely rovat az adott negyedév, a lap profiljába illeszkedő, kiemelkedő tudományos cikkei között tallózott és közölt róluk rövid ismertetőt), valamint a cikkekhez tartozó mellékleteket, amik gyakran nem folyószöveget tartalmaztak. Ennek megfelelően az elemzésünkbe a tanulmányok, adott esetben az ezekhez érkezett reflexiók (a folyóirat számos tematikus vitát bonyolított az évek során, a 2002-ben a technológia, elidegenedés és szabadság kérdésköreit boncolgató disputától a mesterséges intelligencia aktuális kérdéseinek átbeszéléséig 2015-ben), kutatási jelentések, konferencia- és projektbeszámolók, interjúk, recenziók, valamint az INFINIT hírlevélből ${ }^{5}$ átvett cikkek kerültek bele.

Az alapszintű adattisztítást követően az optikai karakterfelismerési folyamat során keletkezett hibákat javítottuk. Mivel az OCR-program betördelt és szkennelt állományokból dolgozott, ezért számos esetben nem tudta tökéletesen felismerni a szövegeket. Jellemzően problémát jelentett a nem szokványosan tördelt (például a normálistól eltérő betűmérettel vagy karakterközzel rendelkező) rész-

\footnotetext{
${ }^{4}$ Bizonyos PDF-fájlok két rétegben tartalmaznak információt: a szkennelt, képként szereplő szöveg „felett” egy OCR-réteg (Optical Character Recognition - Optikai karakterfelismerés) szerepel, amelyen digitalizált formában megtalálható a szkennelt képen olvasható szöveg. Az ilyen dokumentumokból könnyen kinyerhető a számítógép által feldolgozható, szerkeszthető szöveg.

${ }^{5}$ Az INFINIT (INFormációs társadalom, INternet, Információ Technika) a BME-ITTK elektronikus heti hírlevele volt, amely 1999-től 2010-ig készült, a folyóirat egy rovata a hírlevél kiemelkedő cikkeit szemlézte.
} 
letek felismerése ${ }^{6}$, az elválasztások kezelése ${ }^{7}$, az oldaltörések elhelyezése ${ }^{8}$, illetve az ékezetek felismerése ${ }^{9}$. Azokat a problémákat, amelyek kiszámítható módon mindenütt egységesen jelentek meg, Python-ban, programozottan javítottuk, az egyéb hibákat pedig manuálisan, szövegszerkesztőben orvosoltuk. Elemzésünk alapegységét az egyes cikkek, recenziók stb. alkották - az 56 feldolgozott lapszámból összesen 460 darab cikket mentettünk. A topikmodellezés szempontjából fontos információ, hogy folyóirat már a második évfolyamtól, az evolúció témakörét feldolgozó lapszámtól kezdődően folyamatosan jelentetett meg tematikus számokat, amelyek egyrészt az adott időszak fontosabb trendjeiről, illetve e trendek a szerkesztőbizottság általi recepciójáról is tudósítanak. A tematikus lapszámok (24) listája a mellékletben található táblázatban olvasható.

A topikmodellek alkalmazását megelőzi egy úgynevezett előfeldolgozási szakasz, amely során különböző transzformációkat, egyszerüsítéseket végzünk a szövegen annak érdekében, hogy a modellek megfelelően működjenek, eredményük interpretálható legyen. Ezek a lépések azt a célt szolgálják, hogy a szövegkorpuszt megszabadítsák olyan túl általános - vagy éppenséggel túlzottan ritka - szavaktól, kifejezésektől, amelyek torzítanák az eredményeket, továbbá cél az is, hogy a szövegben megfelelő gyakorisággal előforduló szavak különböző ragozott vagy eltérő írásmódú formáit azonos alakra hozva a modellek teljesítményét növeljük. Az alábbiakban röviden ismertetjük az általunk alkalmazott előfeldolgozási lépéseket. ${ }^{10}$

Első lépésként a webcímeket, URL-eket távolítottuk el a szövegekből, ${ }^{11}$ mivel ezek nem tekinthetők a folyószöveg részének, az előfeldolgozás további részében pedig gyakran feldarabolódnak. Ezt követően lemmatizálást, szótövezést végeztünk a korpuszon. A lemmatizálás során az a cél, hogy a szavak toldalékolt formáit kicseréljük a szavak lemmájával, azaz szótövével, tehát egyfajta standardizálást ${ }^{12}$ végzünk. A lemmatizálás során a HuNLP (Orosz 2017) nevü

\footnotetext{
${ }^{6}$ A címsorok és az alcímek számos esetben törlésre kerültek, mivel az OCR gyakran a karakterek közé kiszámíthatatlan módon szóközöket rakott, ezeknek a javítása pedig rendkívül időigényes lett volna.

${ }^{7}$ Az elválasztott szavak egy gondolatjellel és egy szóközzel kerültek elválasztásra, így ezeknek a javítása lehetséges volt automatizált, programozott módon.

${ }^{8}$ Az OCR minden lap végére oldaltörést helyezett el, így - a tördelés miatt - az oldaltörések gyakran elválasztott szavak közepén jelentek meg.

Az OCR-hez használt szoftver a magyartól eltérő, „hullámos” ékezeteket alkalmazott.

${ }^{10}$ Fontos megjegyezni, hogy ugyan léteznek általánosan elfogadott alapelvek az előfeldolgozásra vonatkozóan, még sincs olyan procedúra, amely minden korpuszra és minden nyelvre általánosan megfelelő lenne. A tartalmi és nyelvi sajátosságok miatt minden topikmodellezést célszerű az előfeldolgozási lépések tesztelésével kezdeni, amelynek során akár előzetes modellek futtatásával meggyőződhetünk arról, hogy az általunk követett előfeldolgozási procedúra az adott projekt esetében is megfelelő teljesítményt mutat.

${ }^{11}$ Ehhez az urlextract (Lipovský) Python-csomagot használtuk.

12 Például a „legelképesztőbb” szót kicseréljük az „elképesztő” szóval, vagy a „kollégámtól” szót a „kolléga” szóval.
} 
csomagot használtuk, amely képes szófajfelismerésre is. Ebben a kutatásban a mellékneveket, határozószavakat, főneveket, számokat, illetve tulajdonneveket tartottuk meg a szövegben. ${ }^{13}$ Már ebben a lépésben eltávolítottunk olyan, túlzottan általános, és a cikkek témájának azonosítását nem befolyásoló szavakat, mint például: lásd, ábra, táblázat, forrás.

A harmadik lépésben tulajdonnév-felismerést (Named Entity Recognition, röviden NER) futtattunk. A tulajdonnév-felismerés célja a személy- és intézménynevek felismerése, és az eltérő írásmódok azonos formára hozása. Ilyen módon tehát a „Magyar Távirati Iroda”, az „MTI” és a „Távirati Iroda” megnevezéseket képesek vagyunk egységesíteni, és - ebben az esetben - „Magyar_Távirati_Iroda"14 alakra cserélni a teljes korpuszban. A tulajdonnevek felismeréséhez a dbPedia Spotlight (Daiber és mtsai. 2013) nevű eszközt használtuk, amely a Wikipedia adatbázisán alapszik. Az eszköz hibás találatainak ${ }^{15}$ kezelését egy korábbi kutatásban (Barna és Knap 2019) létrehozott listával kezeltük.

A következő lépésben szignifikáns bigramokat és trigramokat, azaz olyan szókettősöket és szóhármasokat kerestünk egy algoritmus segítségével, amelyek egymással gyakran előforduló szavakból állnak, és egymással együtt értelmesek, így célszerü összevonni, és egy szóként szerepeltetni őket a modellekben. Az összevont kifejezések közé tartozott például az „információs szegénység”, „információs társadalom”, a „big data”, az „,emberi jogok”, a „digitális bölcsészet”, illetve a „nyílt forráskódú szoftver”. Több mint ötszáz ilyen kifejezést vontunk össze a teljes korpuszban.

Az ötödik és a hatodik lépésben szócseréket és stopszavazást végeztünk. A szócserék azt a célt szolgálták, hogy a korábbi előfeldolgozási lépések során előforduló hibákat, hiányosságokat javítsuk, és ezzel tovább egységesítsük a korpuszt. Így például a „határ_túli” szót „határon_túli”-ra cseréltük ${ }^{16}$, illetve számos esetben az „¡” melléknévképzőtől fosztottuk meg a szavakat. A stopszavazás során eltávolítottuk a korpuszból a töltelékszavakat, azokat a szavakat, amelyek kontextus nélkül értelmetlenek (például közel, távol, tegnap, holnap), illetve a keresztneveket (amelyek nem kerültek a megelőző lépésekben összevonásra valamilyen vezetéknévvel).

Végezetül gyakoriságalapú szűrést végeztünk a korpuszon, amelynek során töröltük a túl gyakori (a cikkek több mint 70 százalékában előforduló), a túl

\footnotetext{
${ }^{13}$ A tapasztalatunk azt mutatja, hogy topikmodellezés során legtöbbször nem érdemes az igéket benntartani a korpuszban, mivel a modellek kialakításához és értelmezéséhez nem ad hozzá, viszont a túl gyakori igék miatt a topikok jellemzésére használt szólisták kevésbé lesznek interpretálhatók.

${ }^{14}$ A topikmodellezés során a több szóból álló neveket, kifejezéseket alulvonással vonjuk öszsze, így egy elemzési egységként szerepelnek a modellekben.

${ }^{15}$ A program például a „mag” szót „Atommag”-ra, a „Lajos” keresztnevet „I. Lajos magyar király”-ra cserélte.

${ }^{16}$ Itt a lemmatizálás a „határon” szót „határ”-ra cserélte, majd szignifikáns bigramként összevonásra került a kifejezés.
} 
ritka (kevesebb mint három cikkben előforduló), illetve a túl rövid (kevesebb mint három karakteres) szavakat.

LDA-topikmodellezés esetén a kutató előre meghatározza a topikok számát, amelybe az algoritmus besorolja a dokumentumokat. Természetesen nincs semmilyen hüvelykujjszabály arra nézve, hogy általában mennyi topik lekérése a megfelelő, mivel ez az érték nagyban függ az elemzendő szövegkorpusz méretétől és tematikus összetételétől. Emiatt a megfelelő topikszám meghatározásához a C_v-t (Röder, Both, és Hinneburg 2015) használtuk, amely egy úgynevezett topik-koherencia mutató. Ehhez az előfeldolgozott korpuszon futtattunk előzetes LDA-modelleket, 5 és 30 topik közötti topikszámokkal, minden topikszámra 5 alkalommal. ${ }^{17}$ A modell többszöri futtatásával és a koherenciamutató értékeinek elemzésével képet kaphatunk az optimális topikszámról. A mutató átlagát és szórását vizsgálva úgy találtuk, hogy az Információs Társadalom korpusz esetében a megfelelő topikszám a 10 lesz.

\section{A topikok elemzése}

Az alábbi táblázat tartalmazza az elemzés során kialakul 10 topikot és azok kulcsszavait. Ezek a kulcsszavak nem egyszerü gyakoriságon alapulnak, hanem a szavak informativitása (saliency) a mérvadó, tehát az, hogy egy adott szó mennyire jellemzi a topikot egy véletlenszerüen kiválasztott kifejezéshez képest (Chuang, Manning, és Heer 2012). Topikmodellezés során kialakuló topikokhoz tartozó kulcsszavakból, az átláthatóság kedvéért, a táblázatban csak az első tízet tüntetjük fel, de az inftars.rc2s2.eu oldalon elérhető az összes kulcsszó a topikok interaktív vizualizációján. A topikokat azok kulcsszavai és a topikhoz sorolt cikkek alapján ruházhatjuk fel jelentéssel, melyeket néhány szóba, egy-egy kifejezésbe sürítve neveztük el a topikokat.

\begin{tabular}{|c|l|l|c|}
\hline & Elnevezés & \multicolumn{1}{|c|}{ Kulcsszavak } & $\begin{array}{c}\text { Cikkek } \\
\text { száma }\end{array}$ \\
\hline 1 & E-befogadás & $\begin{array}{l}\text { internet, idős, társadalmi, csoport, használat, } \\
\text { fiatal, program, számítógép, százalék, kör }\end{array}$ & 54 \\
\hline 2 & Fejlesztés & $\begin{array}{l}\text { rendszer, szolgáltatás, fejlesztés, terület, } \\
\text { cél, szervezet, folyamat, innováció, projekt, } \\
\text { megoldás }\end{array}$ & 59 \\
\hline 3 & Oktatás & $\begin{array}{l}\text { oktatás, tanulás, tanuló, diák, oktatási, tudás, } \\
\text { eszköz, kurzus, tanár, hallgató }\end{array}$ & 40 \\
\hline
\end{tabular}

\footnotetext{
${ }^{17}$ Mivel az LDA-modellek véletlen számokon alapuló mintavételezési eljárásokat alkalmaznak, ezért azonos paraméterbeállításokkal, azonos korpuszon futtatva sem adják vissza többszöri futtatás esetében pontosan ugyanazokat az eredményeket.
} 


\begin{tabular}{|c|c|l|c|}
\hline 4 & Internet és közösségek & $\begin{array}{l}\text { játék, szerző, kutatás, játékos, téma, média, } \\
\text { rész, fontos, e-sport, magyar }\end{array}$ & 38 \\
\hline 5 & Privacy, adatvédelem & $\begin{array}{l}\text { adat, jog, eset, rendszer, cél, védelem, érdek, } \\
\text { információ, jogi, biztonság }\end{array}$ & 30 \\
\hline 6 & $\begin{array}{c}\text { Az információs } \\
\text { társadalom elmélete }\end{array}$ & $\begin{array}{l}\text { társadalmi, információ, fogalom, társadalom, } \\
\text { tudás, elmélet, közösség, változás, } \\
\text { információs, kultúra }\end{array}$ & 91 \\
\hline 7 & $\begin{array}{c}\text { Az információs } \\
\text { társadalom empirikus } \\
\text { megközelítésben }\end{array}$ & $\begin{array}{l}\text { eredmény, kapcsolat, kutatás, eset, adat, } \\
\text { vizsgálat, alap, hatás, szint, elemzés }\end{array}$ & 23 \\
\hline 9 & $\begin{array}{l}\text { Mesterséges } \\
\text { intelligencia }\end{array}$ & $\begin{array}{l}\text { ember, világ, emberi, rendszer, képes, gép, } \\
\text { sor, kép, szó, élet }\end{array}$ & 45 \\
\hline 10 & Hálózatok, rendszerek & $\begin{array}{l}\text { információs_társadalom, ország, gazdasági, } \\
\text { társadalom, politikai, gazdaság, társadalmi, } \\
\text { hálózat, amerikai_egyesült_államok, világ }\end{array}$ & 35 \\
\hline
\end{tabular}

1. táblázat: Az LDA által kinyert topikokra jellemző kulcsszavak listája

Korábban írtuk, hogy egy cikk topikok keveredéseként értelmezhető. Az elemzés során a könnyebb interpretálhatóság kedvéért a cikkeket besoroltuk ahhoz a topikhoz, amely a legjellemzőbb rá, amely a cikkben a legdominánsabb szerepet kapja, és a további elemzéseket ez alapján a besorolás alapján végeztük.

\section{E-befogadás}

Az első topik, kulcsszavai alapján a számítógéppel, internettel és az azokat használó társadalmi csoportokkal foglalkozik, így megjelenik a legfontosabb szavak között az internet, az idős, a fiatal, a csoport vagy a százalék. A topikon átívelő legfőbb momentum az internethez történő hozzáférés, illetve a digitális szolgáltatások használatában tetten érhető különbségek és egyenlőtlenségek kérdése, valamint a meglévő egyenlőtlenségek és a digitalizáció viszonya. A tanulmányok (különösen az első évek írásai) elsősorban az életkori csoportok perspektíváját vizsgálják, de más, csoportképző dimenziók is megjelennek. A topik viszonylag sok, 54 tanulmányban szerepel, mint a legjellemzőbb topik, elsősorban 2010 előttről (35 cikk), aminek egyik magyarázata lehet, hogy az internet terjedésének korai szakaszában megkülönböztetett figyelem övezte az internethasználatból kimaradó, vagy azt a társadalom többi szegmenséhez képest lassabban adaptáló csoportokat. A topikhoz tartozó tanulmányok jelentős részét három (tematikus) lapszám adja. Hét olyan munkát is találunk 
az Információs Társadalom Szakmai Napok (ITSZN) 2006-os konferencia-számában, ami ehhez a topikhoz tartozik (Z. Karvalics 2006; Csepeli 2006). A lapszám az ötödik, Információs Társadalom és Szociális Integráció című ITSZN konferencia fontosabb előadásait gyüjtötte össze, nem meglepő, hogy a közölt írások döntő többsége ebbe a topikba került. A másik két tematikus szám is szorosan kötődik a digitális egyenlőtlenségekhez, illetve kiemelten a generációs különbségekhez: hat-hat, topikba sorolt tanulmányt tartalmaz a befogadó információs társadalommal (e-Inclusion) foglalkozó 2008. évi 2. szám, illetve az „idősödő információs társadalom”, az idősebb korosztályok internethasználatát (Rab 2009; Gyarmati 2009) körül járó 2009/4. szám (például: Galácz és Ságvári 2008; Farkas, Gyarmati és Molnár 2009). A Galácz Anna és Ságvári Bence jegyezte tanulmány ugyanakkor már azt is mutatja, hogy a hangsúly a hozzáférésben jelentkező különbségekről folyamatosan áthelyeződött a használati mintázatokban, illetve a mindennapi élet alakításában jelentkező különbségekre. Ezt a hangsúlyeltolódást jól illusztrálja a topikra jellemző legfrissebb cikkeket tartalmazó, 2017-ben megjelent Digitális szegénység című tematikus szám (S. Molnár 2017; Csepeli 2017). A topikhoz tartozó cikkekben (a téma fókuszának lassú áthelyeződését is követve) eleinte a digitális fejlődéshez való hozzájutás esélyeit (köztük például a közösségi hozzáférési pontokról szóló és az ahhoz elsősorban kapcsolódó, a településtípusok között tetten érhető eltérésekre reflektáló teleházakat ${ }^{18}$ (Hohl 2006), később a médiafogyasztásban, a technológiák használatában megjelenő státuscsoportok kérdését tárgyalják (például Bernát és mtsai. 2008). A tanulmányok több esetben a témához kapcsolódó projektek értékelésével foglalkoznak (például cserénfai kísérlet (Eranus, Lengyel, és Siklós 2006) vagy e-Inclusion (Futó és Kollányi 2007)). A 2010-es évek második felében az információs társadalomhoz kapcsolódó generációs különbségekről (internethasználat, médiafogyasztás, szabadidős tevékenységek (Hack-Handa és Pinter 2015; L. Székely 2017)) és a digitális egyenlőtlenségek újabb megjelenési formái, illetve az azokra adható válaszok (S. Molnár 2017; Sólyom 2017) továbbra is a topik relevanciájának tovább élését mutatják, bár a topikok idődimenzióit mutató 1. ábra alapján ennek a témának a lapban történő reprezentációja enyhe csökkenést mutat. Ennek ellenére várhatóan a továbbiakban is jelen lesz (lásd a kézirat lezárásakor megjelent lapszámban például (Vida 2020)), nem utolsó sorban a Covid-19-világjárvány hatásának köszönhetően, mely olyan fontos területeken mutatott rá markánsan a kimaradó társadalmi csoportok depriváltságára, mint az oktatás vagy az egészségügy.

A legtöbb publikációval rendelkező szerzők a topikban Molnár Szilárd és Székely Levente, akik négy-négy publikációt jegyeznek. Mellettük Csepeli

\footnotetext{
18 A teleházak elsősorban kistelepüléseken létesültek, ahol sokak számára nem voltak elérhetőek digitális eszközök, mint számítógép, nyomtató, fénymásoló, fax és internet. A teleházakban ezek elérhetővé váltak a lakosoknak, így segítve ledolgozni a kistelepülésen élők hátrányát a digitális eszközökhöz való hozzáférésben.
} 
György, Dombi Gábor, Kollányi Bence és Z. Karvalics László nevét találjuk 3-3 cikknél. A tanulmányok alapján elmondhatjuk, hogy ez a topik olyan cikkeket foglal magában, amelyek a digitális világ elérhetőségével, és az abból adódó egyenlőtlenségekkel foglalkoznak, a digitalizációt a szociálpolitika aspektusából vizsgálva, a szerzők és a tematikus számok alapján pedig az is látható, hogy a folyóirat alapítása mögött lévő szellemi műhely ezen a területen kiemelten aktív volt.

\section{Fejlesztés}

A második topikba annak legrelevánsabb szavai (például rendszer, szolgáltatás, cél, innováció, projekt) alapján az információs társadalomhoz kötődő fejlesztésekkel, projektekkel, illetve magával az információs társadalommal, vagy annak valamilyen részterületének fejlesztéspolitikai, rendszerszintü megközelítésével foglalkozó tanulmányok tartoznak. A gyakoribb részterületeket az ehhez a topikhoz legjobban köthető két tematikus szám is jól körvonalazza: a 2007-ben megjelenő, e-közigazgatással foglalkozó szám kilenc tanulmányában is ez a legjellemzőbb topik (Juhász 2007; Krasznai és Szakolyi 2007), ahogy a 2016-os okosvárosokkal foglalkozó szám nyolc tanulmányában is (Ders 2017; Kun 2017). Az ebben a topikban megjelenő témák elsősorban arról árulkodnak, hogy az információs társadalom nagy témakörén belül melyek azok a szegmensek, amelyek esetében a folyóiratban megjelent írások beszédmódjában a fejlesztés kerül előtérbe - az elektronikus közigazgatás és az okosvárosok területe klasszikusan ilyen témakör, ahol a diskurzus általában valamilyen célállapot eléréséről, és az addig vezető útról szól. Ide köthető még néhány, a topikban szintén megjelenő résztéma is (nyílt forráskódú szoftverek, közgyűjtemények/könyvtárak), de számos írás foglalkozik általánosan az információs társadalom fejlesztésével, az ehhez a területhez köthető különböző szakpolitikával (Bak 2006, Z. Karvalics, Molnár és Pintér 2007, Kis 2011). Nem véletlen tehát, hogy ez a második legtöbb cikket tartalmazó topik, összesen 59 tanulmánnyal. Szintén ebbe a topikba tartozik a „Kutatás-fejlesztés-innováció” és az „Információs társadalom kutatás a Szegedi Tudományegyetemen” tematikus számok 4-4 publikációja, vagyis az elsősorban a privát vagy az akadémiai szféra kutatásaival, illetve az arra épülő innovációs folyamatokkal és fejlesztésekkel foglalkozó írások (Lippényi, Imre és Peredy 2006), melyek között előfordulnak projekteket bemutató és értékelő tanulmányok is (Hronszky 2006; Vilmányi és Révészné Kocsis 2012), azonban nincs jellegzetes téma e tematikus számokon belül. Az említett tematikus lapszámok a topikba sorolt tanulmányain túl megjelenik még például az üzleti intelligencia (Galli 2012, Görcsi, Barta és Széles 2019) vagy az intelligens közlekedési rendszerek (Krauth 2010) témája is. Jellemzőek a konferenciabeszámolók is, melyek általában az aktuálisan zajló projektekről, kutatásokról, tervekről, fejlesztéspolitikáról tudósítanak, így óhatatlanul leginkább ide kerültek. Az általunk 
vizsgált időszakban végig előfordultak olyan tanulmányok, amelyre ez a legjellemzőbb topik, ez pedig szintén azt támasztja alá, hogy az innovációval, megvalósult projektekkel foglalkozó tanulmányok markáns részét képezik a folyóirat cikkeinek. Szerzők tekintetében elmondható, hogy Csótó Mihály öt tanulmányt is jegyez önállóan a topikban (és egyet társszerzővel), amelyek elsősorban konferenciabeszámolók. ${ }^{19}$ Rab Árpád hét, általunk feldolgozott tanulmányából pedig három ebben a topikban található. Az idődimenziót tekintve elmondható, hogy a fejlesztés topik jelenléte folyamatosnak tekinthető.

\section{Oktatás}

A harmadik topikba tartoznak a tudásátadással, oktatással kapcsolatban írt tanulmányok, amelyeket egyebek mellett az oktatás, tanulás, diák, tudás, kurzus, tanár kulcsszavak jelölnek. Ezek a cikkek elsősorban a digitális technológia oktatásban történő megjelenéséről szólnak, részletesebben megjelennek e-learninggel kapcsolatos tapasztalatokat (például blended learning, e-learning, MOOC) taglaló cikkek, a különböző IKT-eszközökhöz való hozzáférhetőség és azok használata (például a virtuális valóság lehetőségei az oktatásban). A tanulmányok jelentős része tekinthető gyakorlatitudás-átadásnak, mivel a szerzők saját tapasztalataikat vagy az eszközökben rejlő lehetőséget ismertetik a szakmával (Kalvet 2008; Námesztovszki és mtsai. 2015). Azonban nemcsak gyakorlati tapasztalatok jelennek meg a cikkekben: néhány tanulmány a digitalizáció oktatásra gyakorolt hatásait taglalja, illetve az információs korszak oktatási, tanulási modelljeinek, jellemzőinek rendszerszintű áttekintésére vállalkozik (Duma és Monda 2012; Ollé 2012, Stoffa 2008). Fontos megemlíteni, hogy a tanulmányok a köz- és felsőoktatással egyaránt foglalkoznak. Érdekesség, hogy a 2009/2. és a 2012/3. szám közötti időszakban megjelent írások közül egy sem tartozik ebbe a topikba, igaz, ebben az időszakban több tematikus szám jelent meg egyéb témákban, miközben a tudományos lapokat gyakran sújtó forrásszegénység az Információs Társadalmat is elérte, így 2011-ben csak egy, összevont lapszám jelent meg. A 2012-ben megjelenő szám azonban pótolta a kimaradást, és kifejezetten az oktatással foglalkozott: a lap hét cikkéből öt ehhez a topikhoz sorolható (Ollé 2012; Hülber 2012). Gyakorlatilag teljes egészében a témával foglalkozik a 2008. évfolyam 3. szám („Hálózat az információs társadalom tanításáért”), az abban helyet kapó 13 tanulmányból nyolc esetében ez a legjellemzőbb topik (Tóth és Bessenyei 2008; Pintér

\footnotetext{
${ }^{19}$ A konferenciabeszámolók a 2000-es évek második felében jelentek meg a lapban, illetve váltották fel az első három évfolyam Konferencia Figyelő rovatát. Kezdetben ennek a folyamatnak a katalizátora az ITTK egyik spin off cégének, az Infinit Intelligence-nek Konferencia Tudásbank szolgáltatásának indulása volt, mely végül nem futott be hosszabb távon fenntartható pályát, ellentétben a részben általa inspirált rovattal, mely a mai napig a folyóirat szerves részét képezi.
} 
2008b). Ebben a lapszámban jelent meg ugyanis több beszámoló a NETIS (Network for Teaching Information Society) projektről és annak tapasztalatairól. A NETIS-projekt célja az információs társadalom témájú, alapszakos hallgatók számára készült kurrikulum kidolgozása volt (Pintér 2008b; Bessenyei és Tóth 2008). Az egyes kifejezések meghonosulásának szempontjából érdemes megjegyezni, hogy a korai cikkekben olyan, napjainkban kevésbé elterjedt kifejezések szerepelnek, mint „VLE - virtuális tanulókörnyezet” (Tóth és Bessenyei 2008) vagy „hálózati tanulás” (Bessenyei 2005). Érdekesség, hogy csak három tanulmány található ebben a topikban a 2014. évi első számból, amely kifejezetten az „eLearning fejlesztések a közszolgálatban” témában jelent meg (Szani és Merkovity 2014; Csedő és mtsai. 2014; Monda 2014), melynek legfőbb oka, hogy ez egy, a Nemzeti Közszolgálati Egyetem vonatkozó fejlesztéseit áttekintő kiadvány, ahol a vendégszerkesztők (Merkovity Norbert és Nemeslaki András) olyan kapcsolódó, a topikelemzésben máshol artikulálódó területeknek is teret biztosítottak, mint az e-közigazgatás vagy az információbiztonság. Az idődimenziót tekintve az oktatás fontos topik az Információs Társadalomban, csak néhány évben nem találunk ehhez a témához sorolható cikket. A trendek alapján az elméleti megközelítés mellett (a digitális technológia széles körű elterjedésével) egyre markánsabban vannak jelen a gyakorlati tapasztalatokat rendszerező írások. A tanulmányok szerzőit vizsgálva láthatjuk, hogy jellemzően szerzőpárosok, különböző szerzőcsoportok jelennek meg többször a topikhoz tartozó tanulmányok esetén, nincs egy-két domináns szerző.

\section{Internet és közösségek}

A negyedik elkülönülő tematikus egységet az online játékokkal, e-sporttal, közösségi médiával foglalkozó tanulmányok alkotják. A topikba 38 tanulmány sorolható, melyből 34 2012-ben vagy utána jelent meg, így ez a többi topikhoz képest viszonylag új területe a folyóiratnak, tükrözve a topik témáinak hazai elterjedtségét. A topikhoz köthető írásokat az online közösségekkel kapcsolatos jelenségek, az interperszonális viszonyok digitális környezetben zajló dinamikájának vizsgálata jellemzi leginkább. A topik felfutására egyfajta magyarázat lehet, hogy a különböző platformok (például közösségi média, MMORPG-k) körül kialakuló közösségeket a 2000-es évek közepétől jelentősen támogatta a (mobil) szélessávú internetelérés, valamint a felhasználói tartalommegosztást támogató szolgáltatások és technológiák széles körü elterjedése. Beszédes, hogy 2010 előtt mindössze négy publikáció tartozik a topikhoz, melyek a közösségi szál miatt tartozhatnak a topikhoz: három konferenciabeszámoló online publikációról (tudományos eredmények megosztása a kutatói közösséggel), online kutatásról és társadalmi (azaz közösségi) informatikáról szóló konferenciákról (Pintér 2006; L. Székely 2007; Pintér 2009), egy pedig az internet szerepét vizsgálja konkrét közösség, az alternatív mozgalmak dinamikájában (Mikecz 2007). Pintér Róbert 2009-es, az online kutatásról szóló konferenciabeszámolójának 
központi eleme pedig a „netnográfia”, az akkoriban internetes néprajznak nevezett megközelítés felemelkedése (,....amely a webkettő előretörésével lett egyre hangsúlyosabb: ahogy nő a közösségi tartalom a weben, úgy válik lehetővé, hogy ne kérdőívek útján kérdezzék meg az embereket, hanem azt elemezzék, amit azok maguktól is közzétesznek blogbejegyzések, mikroblogok, státusüzenetek, fórummegszólalások, fotók és videók formájában.” (Pintér 2009, 106)), ami szintén kiváló indikátora a témakör növekvő súlyának. Még inkább alátámasztja a téma újdonságát, hogy a topikhoz köthető tanulmányok közül 20 az utóbbi négy évben jelent meg, illetve az, hogy a folyóirat 2018-ban egy tematikus számot szentelt a játékoknak és az e-sportnak. Az azévi első szám Videojáték és e-sport címmel jelent meg, és a lap szinte mindegyik cikkében, összesen 11ben ez a leginkább jellemző topik (Bányai és mtsai. 2018; Szabella 2018), a tematikus lapszámban az e-sport mellett olyan, a játékokhoz kapcsolódó témákról esik szó, mint a gamifikáció, játékosítás (Fromann és Damsa 2018). A tematikus számon kívül azonban viszonylag szerteágazó témák jelennek meg a topikban az imázsformálástól (Sulyok 2012) a radikalizmuson és az interneten át (Iványi 2014) egészen a közösségi oldalakról önként vállalt száműzetésig (social silence) (Mihalik 2020), vagy akár az olyan sikamlósabb témákig, mint a közösségi normák különböző, réspiacot szolgáló társkereső oldalakon (Bokor 2015, Dessewffy, Gurály és Mezei 2018). A topik a szerzők szempontjából is sokszínü: a legtöbb szerző 1-2 tanulmánnyal szerepel benne, csupán ketten, Pintér Róbert és Tóth János jegyeznek több publikációt (ők is csak hármat - hármat), azonban míg előbbi két cikke 2010 előtt jelent meg, utóbbi 2014 óta ír csak a lapba.

\section{Privacy, adatvédelem}

Az ötödik topikba tömörülnek az adat, jog, eset, érdek, biztonság kulcsszavak alapján a magánélet védelmének (privacy) az információs társadalom kiterjedésével előtérbe kerülő aspektusai, mint például az adatbiztonság vagy az adatvédelem. Ahogy az 1 . ábrán látható, a topik rendszeresen megjelent az elmúlt 15 év lapszámaiban, és már 2005-ben tematikus szám foglalkozott az adatbiztonsággal, benne például a nyilvános arcfelismerő rendszerek kockázatait taglaló tanulmánnyal (Agre 2005), melynek különös aktualitást ad az e rendszerek mesterséges intelligenciával támogatott, újabb generációja kapcsán napjainkban fellángolt élénk disputa. Az elmúlt években az adatvédelem még inkább előtérbe került, ennek megfelelően a 2017. évi 1. szám is a biztonság és magánélet viszonyrendszerével foglalkozik. ${ }^{20} \mathrm{Az}$ adatvédelemhez tágabban kapcsolódó témák is előfordulnak a topikban, amelyek inkább jog-

\footnotetext{
${ }^{20}$ Részletesebb tájékozódáshoz remek kiindulópont a gazdagon illusztrált angol nyelvű Webes összefoglaló: https://www8.cao.go.jp/cstp/english/society5 0/index.html. A Society 5.0 koncepció Japán 5. Tudományos és Technológia Alaptervének (5th Science and Technology Basic Plan) volt része. Nagyívű elemzését lásd Holroyd (2020).
} 
elméleti kérdéseket feszegetnek, például a szólásszabadságot (Vári 2019) vagy a felejtés jogát (I. Székely 2013), de az elektronikus kormányzathoz kötődő, az egyének identitására fókuszáló írások is előfordulnak benne, mint például az észtországi e-votinggal és e-polgársággal foglalkozó tanulmányokban (Särav, Kerikmäe, és Kasper 2016; Mikecz 2009). A szabályozási kérdések és a jogi vonulat szintén erős az olyan további cikkekben, mint a Paks2-ről szóló társadalmi diskurzust (Egres 2020) vagy a technológiai determinizmus jelenlétét a kommunikáció szabályozásában elemző (Polyák 2011) írások. Ebbe a topikba sorolható az egyik legkevesebb tanulmány, összesen 30, amely eredhet abból is, hogy az információs társadalom jogi aspektusai csak szűk oldalágát képezik a területnek. A szerzők között a terület ismert hazai művelőit találjuk, Székely Iván fordul elő szerzőként leggyakrabban, ő négy tanulmánnyal is szerepel, Szabó Máté Dániel pedig mindhárom, a folyóiratban szerzőként vagy társszerzőként megjelent cikke ehhez a témához került (a háromból kettőben mások mellett Székely Ivánnal dolgozott együtt).

\section{Az információs társadalom elmélete}

A hatodik topik a legtágabban értelmezhető „információs társadalom” topik, hiszen kulcsszavaiban tükröződik a fogalom lényege: társadalmi, tudás, információ, közösség, változás - leginkább ide került a legtöbb, a lap fő fókuszához, az információs társadalom jelenségeinek átfogó, rendszerszintű megértését és feldolgozását célzó írás. Ennek megfelelően ez a legnagyobb topik, ugyanis ide tartozik a legtöbb, 91 cikk, ami az összes feldolgozott tanulmány közel ötöde. A tanulmányok témái szerteágazók (mint ahogy az információs társadalmat is számos aspektusból lehet megközelíteni), és minden évben találunk olyan cikket, amelyre ez a legjellemzőbb topik, igaz, 2018-ban csak egy ilyen van (amiben némileg közrejátszik a már említett Videojáték és e-sport tematikus lapszám, valamint egy inkább az empirikus vizsgálatokra és szűkebb résztémák feldolgozását célzó duplaszám is). E megfigyelések jelzik, hogy a folyóirat húsz év alatt sem távolodott el a legelső szám (2001/1.) bevezetőjében megfogalmazott célkitűzésétől, az információs társadalom elméleti megközelítése iránti elkötelezettségtől. A topik nagysága miatt nem uralja egy-egy tematikus szám a topikot, az viszont az idődimenziót mutató ábrán jól látható, hogy a folyóirat első szakaszából különösen sok írás került ide besorolásra. Ennek oka kettős. Egyrészt a lap elindulásakor külön hangsúlyt fektettek a szerkesztők az információs társadalom kiemelkedő és időtálló írásainak magyar nyelvű megjelentetésére (a „Klasszikusok” rovat keretében), mely még az általunk feldolgozott írásokban is tetten érhető. Másrészt az ebben az időszakban megjelent tematikus számok közül több kifejezetten nagyobb elméleti konstrukciók feldolgozására vállalkozott (konzervativizmus az információ korában; az információs társadalom kritikája, a jövő információs társadalma, csoporttudat vagy kollektív intelligencia?), így például a 2006. évi 4. szám nyolc, a konzer- 
vativizmus modern kori mibenlétét boncolgató tanulmánya is ebbe a csoportba került (Karácsony 2006; Nyíri 2006), a 2008-ban megjelent csoporttudattal, kollektív intelligenciával foglalkozó lapszámban pedig hét cikkről mondható el ugyanez, amelyben három tanulmány az értelmiség felelősségéről (Levy 2008; Tamás 2008; Alföldi 2008), egy a csoporttudatról (William 2008), egy a társadalmi konvenciókról (Pete 2008), egy az emlékezetszociológiáról (Jedlowski 2008) szól, egy pedig egy recenzió (András 2008) egy filozófiai témájú könyvről. Székely Iván az adatvédelemről szóló topik mellett ezen általános topikban jegyzi tanulmányait, ez utóbbiban négy önálló munkája szerepel (leginkább a felejtés, valamint az archívumok információs kori lehetőségeit körüljárva), akárcsak Z. Karvalics Lászlónak. A három tanulmánnyal megjelenő szerzők, Fabó Edit, Koltay Tibor és Nico Stehr viszont csak ehhez a topikhoz köthetők.

\section{Az információs társadalom empirikus megközelítésben}

A hetedik topik legrelevánsabb szavai az eredmény, a kapcsolat, a kutatás, az eset, az adat, a vizsgálat, az alap, a hatás, a szint és az elemzés. Ez tehát elsősorban olyan cikkeket tartalmaz, amelyek empirikus (piac)kutatások, közvéleménykutatások, online felmérések eredményeit ismertetik, így a cikkek témái szerteágazóak, megjelenik bennük a gazdaság, a munka világa, a közigazgatás, de a környezetvédelem és a fenntarthatóság is. A topik 23 cikk esetén a legvalószínübb, ezzel ez a legkisebb csoport. Ugyanakkor az is elmondható, hogy viszonylag friss írásokat tartalmaz, mivel a 23 cikk közül csupán kettő született 2010 előtt, és 12 íródott 2015-ben vagy utána. Több tematikus számból is került ide 1-2 cikk, például a 2007-es, információs társadalommal kapcsolatos doktori kutatásokat vagy a 2012-es, Szegedi Tudományegyetemen végzett, információs társadalommal foglalkozó kutatásokat bemutató számok egy-egy cikke. Általánosságban elmondható, hogy a topik jelenléte és az elmúlt egy évtizedben tapasztalható (1. ábra) „kihasználtsága” egy általánosabb trend jelzése lehet: az információs társadalom kiterjedése kapcsán számos olyan változást indukált, amelyek empirikus módszerekkel is jól kutathatóvá váltak, miközben új módszertani megoldások és apparátus is támogatják ezeket a törekvéseket (mint például a jelen írásban használt topikmodellezés. A trend hátterében az is meghúzódhat, hogy mivel egyre több szakterület „itatódott át” az információs és kommunikációs technológiákkal, az ezeken a területeken zajló kutatások, az ott tapasztalható jelenségek immár a folyóirat érdeklődésére is számot tarthattak. Mindezek mellett az Információs Társadalomhoz kapcsolódó műhely, a BME-ITTK, illetve a lapot kiadó INFONIA históriájában is akadunk kapcsolódó előzményre, a Kutatási Jelentés ${ }^{21}$ című kiadványra, amely 1999 és 2005 között jelent meg, és megszűnése után saját rovatot kapott

${ }^{21}$ https://inftars.infonia.hu/kutjel-1999-2005 
a lapban. A kiadvány célja az információs társadalom témakörében megjelent hazai kutatási eredmények közül a releváns, módszertanában megbízható, friss empirikus kutatások anyagainak összegyüjtése volt. A topik cikkei közül mindet más szerző írta Eszenyiné Borbély Mária kivételével, aki két tanulmányt is jegyez. A topikba tartozó cikkek szerzőinek nagy részére igaz az is, hogy csupán egy cikke jelent meg a folyóiratban.

\section{Mesterséges intelligencia}

A nyolcadik topik a kollektív és mesterséges intelligencia topikja, melyben már a topikok kulcsszavait vizsgálva is egyértelműen megjelenik az ember, a világ és a gép viszonya, illetve emellett a művészet, az irodalom (a kulcsszavakban: sor, kép, szó) és az „élet” maga. A topikhoz 45 cikk tartozik, melyből 14 Z. Karvalics László (társ)szerzőségében jelent meg - Z. Karvalics cikkeinek közel fele ebben a topikban található. Három cikk Bátfai Norbertnek és 2-2 Pokol Bélának, valamint Síklaki Istvánnak köszönhetően született meg, de Csepeli György neve is felbukkan a szerzők között. A topik igen sok tematikus számot gyüjt, amelyek két hullámban jelentek meg (1. ábra). Egyrészt a 2000-es évek második felében (18 tanulmány): a 2008-as Csoporttudat vagy kollektív intelligencia? címet viselő számból 7, a 2009-es, művészet és információs társadalom kapcsolatát (olyan témákon keresztül, mint a programozott számítógépes költészet/generált versek, számítógépes képzőművészet, illetve kiberfilmográfia) feldolgozó számból 5 írás került a topikba. A 2010-es évek közepétől a 2015-ös, Mesterséges intelligencia címet viselő tematikus számtól kezdődően (amelyből gyakorlatilag a teljes lapszám, azaz 6 cikk került ebbe a topikba) a topik erősödése tapasztalható, a 2018-as Videojáték és e-sport tematikájú számból két, inkább kognitív jelenségekkel foglalkozó cikk is helyet kapott ebben a tematikus csoportban. Ez a növekvő gyakoriság jól tükrözi a mesterséges intelligencia jelenkori népszerüségének (egy újabb MI tavasz vagy az MI szervesülésének) időszakát.

\section{Új média}

A kilencedik topik az internet köré szerveződik, olyan kulcsszavakkal, mint a tartalom, a média, a lehetőségek, a felhasználó, az internet, a digitális, a hálózat vagy az oldal. A topik 45 tanulmánya szinte a teljes időszakot lefedi, csupán 2005-ből és 2017-ből-hiányoznak esetek, 2007-2008-tól, az új média kifejezés hazai meghonosodásától kezdve folyamatosan jelen lévő téma, amelyhez sorolt tanulmányok középpontjában a tartalomfogyasztás és a kommunikáció megújuló formái állnak, beleértve a felhasználók által generált tartalmak különböző aspektusait. Elmondható, hogy nincs egy igazán domináns, tematikus szám, amely cikkeinek többségét e topik adná, azonban a 2011-ben egyedü- 
liként megjelenő, összevont számban 5 tanulmány is helyet kapott a témában, 2014-ben pedig mind a négy számban megjelent összesen 7 cikk. A topik legtermékenyebb szerzője Yoo Jinil, aki szintén médiakutató társszerzőjével, Szüts Zoltánnal jegyzett öt tanulmánya mellett kettőt önállóan is írt a topikba tartozó cikkek közül (Szüts Zoltán egy további tanulmánnyal szerepel). A szerzőpáros cikkei a tartalomfogyasztás és az online médiafelületek kulturális sajátosságaival foglalkoztak, olyan példákon keresztül, mint a kiterjesztett valóság (Szűts és Jinil 2013, szintén ír a témáról Balkányi és Orbán 2011), vagy a chatbotok (Szűts és Jinil 2018), de a netsemlegesség szintén kapcsolatban áll az online tartalmakkal (Szűts és Jinil 2015), továbbá külön-külön jegyeznek cikkeket a koreai információs társadalomról (Jinil 2014; Szűts 2014). Mellettük Pintér Róbert neve fordul elő legtöbbször a topikban, aki négy tanulmányt írt okostelefonokkal (Pintér 2011), felhasználók által létrehozott tartalommal kapcsolatban (Pintér 2008a), illetve írt egy recenziót is a WTF?! című könyvről (Pintér 2018). Míg a topikban kezdetekben a tartalomkészítés és megosztás (akkoriban) új módja, a blog (Pintér 2008; Ughy 2007, Zsigó 2008) és a felhasználók által létrehozott tartalmak szerzői jogi kérdései (Rátai és Szemes 2008; Ughy 2007) voltak a kulcstémák, később, a 2010-es évekre az új média általános vagy metszeti (Youtube-sztárok) jellemzői (Fehér 2013; Glózer és Guld 2015), valamint az új média fogyasztásának egyre kiemelkedőbb eszköze, az okostelefon, valamint annak használati mintázatai kerültek előtérbe (Sólyom 2016; Pintér 2010). Emellett több tanulmány foglalkozik médiakonvergenciával, digitális televíziózással (Székely és Urbán 2008; Koltai 2010), a könyvek szerepéről a digitális kultúrában (Kerekes 2011), illetve a médiagazdaság általános kérdéseivel (Iványi 2019) vagy a közösségi gazdasággal (Kalóz 2015).

\section{Hálózatok, rendszerek}

A tizedik topik legrelevánsabb szavai alapján azt mondhatjuk, hogy ez az információs társadalom egy, Manuel Castells (2005) által leginkább megragadott jellemzőjét, a hálózatiságot ragadja meg, olyan kulcsszavakon keresztül, mint az ország, a gazdasági, a politikai, a gazdaság, a társadalmi, a hálózat és a világ. A topikhoz tartozó 35 cikk közül 25 született 2010 előtt, így ez a téma elsősorban a folyóirat első 10 évében volt jellemző. A korai cikkek közül 6 is a 2005. évi 4. számban jelent meg annak ellenére, hogy az nem tematikus szám volt. Ennek egyik legfőbb oka a részben Castells köré épülő szerkezet, akivel egyrészt interjú olvasható a lapszámban (Rantanen 2005), másrészt a magyarul abban az évben megjelenő trilógiájának első részéről ( $A$ hálózati társadalom kialakulása) találunk recenziót. Emellett ebben a számban a tanulmányok között szerepel a gazdaság, a civil társadalom, a tudomány és a privát szféra kapcsolatrendszerét egy gyémánt modellel leíró tanulmány (Wilson 2005), valamint a virtuális és geográfiai terek tulajdonságainak közösségre gyakorolt hatását az interakciókon keresztül elemző (Vörös 2005), 
illetve a civil szervezetek társadalmi beágyazódásáról szóló (Juhász és Pintér 2005) írás is. További öt tanulmány sorolható a topikba 2006-ból, azon belül is a kutatás, fejlesztés, innováció témájú tematikus számból. Az ekkor megjelenő tanulmányok nemzetközi kitekintésben vizsgálják a $\mathrm{K}+\mathrm{F}$ perspektíváit (Borsi 2006; György 2006; Asheim és Coenen 2006). Az ok, amiért vélhetően ezek az írások nem a második topikhoz kerültek, az a tanulmányok megközelítésében rejlik, amely innovációs rendszerek, illetve az ezeket alkotó aktorok kapcsolatának vizsgálata, országportrékkal (Izrael, Finnország, Észtország) és regionális elemzésekkel (az Egyesült Államok és az Európai Unió innovációs teljesítményének összehasonlítása; a visegrádi országok perspektívái az Európai Kutatási és Innovációs Térségben, skandináviai klaszterek összevetése).

A topik érdekes módon egy harmadik témakör írásait is magába foglalja, amelyet szintén áthat a rendszerszemlélet, ez pedig a fenntarthatóság, illetve a zöld informatika. A 2010-es évek fordulóján a folyóirat több lapszámában jelentek meg (elsősorban a 2009/2 és 3, valamint a hivatalosan is tematikus 2012/4) a környezetvédelemmel, a fenntarthatóság és az információs társadalom kapcsolatának vonatkozásában (Csótó 2009; Fuchs 2009a; 2009b) E számok kivételével elszórtan fordulnak csak elő e topikhoz sorolható cikkek, jellemzően csak 1-2 tanulmány évente, de több olyan év is akadt (2011, 2015, 2017 és 2018), ahonnan egy sem. Ahogy az az 1. ábrán látható, a háromarcú téma jelentősége egyre inkább csökken, ami azért is figyelemre méltó, mert a napjainkban népszerű innovációs vagy digitális ökoszisztéma kifejezéspárok a topikra jellemző kulcsszavakból eredeztethetőek. Az évek mellett a szerzők esetén is változatosság látható: a legtöbb (hat) cikket szerző Z. Karvalics László mellett Pintér Róbert neve három tanulmánynál szerepel, illetve Christian Fuchs írt egy két részben megjelenő munkát, a többi, szám szerint 24, tanulmány különböző szerzők, szerzőcsoportok munkája. Ez az eredmény származhat abból, hogy amint azt láttuk, a topik tulajdonképpen három, egymástól távol álló és rövidebb időre népszerű (a lapban legalábbis kevesebb szerepet kapó) altémából (esetleg annak bizonyos megközelítéséből) tevődik össze, így e területek szakértői sem publikáltak többször a folyóiratban.

\section{A topikok előfordulása az évek során}

Az 1. ábrán a cikkekben a topikok és az idő dimenzióját vizsgáljuk. Ebben az esetben szintén a cikkekre jellemző legdominánsabb topikokból indulunk ki. Mint ahogy az már a topikok ismertetésénél is jeleztük néhány esetben, számos trendet megfigyelhetünk a vizsgált éveket áttekintve. Egyrészt bizonyos témakörök súlya egyértelműen csökkent. Ilyen a digitális esélyegyenlőtlenséggel foglalkozó E-befogadás téma, amely a digitális eszközök széles(ebb) körü terjedésével és az adaptációs görbe ellaposodásával elvesztette az egyik fő összetevőjét, a hozzáférést (access). Az információs társadalom elmélete topik esetén szintén tapasztalható némi visszaesés, mely tendencia talán azzal is magyarázható, hogy a folyóirat kezdeti éveiben kiemelt jelentőségű volt az 
információs társadalom elméleti kérdéseinek ismertetése (beleértve a klaszszikus irodalmakat), a fogalomról való elméleti diskurzus megindítása. A folyóirat ezzel kapcsolatos missziója azonban némileg veszített súlyából, ahogy az információs társadalom jellemvonásai egyre inkább jelentkeztek a hétköznapi életben is, és számos egyéb tudományterületen, amely az empirikus vizsgálatok (és az ezeket ismertető kéziratok) megszaporodását szintén eredményezte. Ezen túl az egyébként sem homogén, Castells-inspirálta, legjobban hálózatokkal, rendszerekkel jellemezhető topik elmaradása tapasztalható.

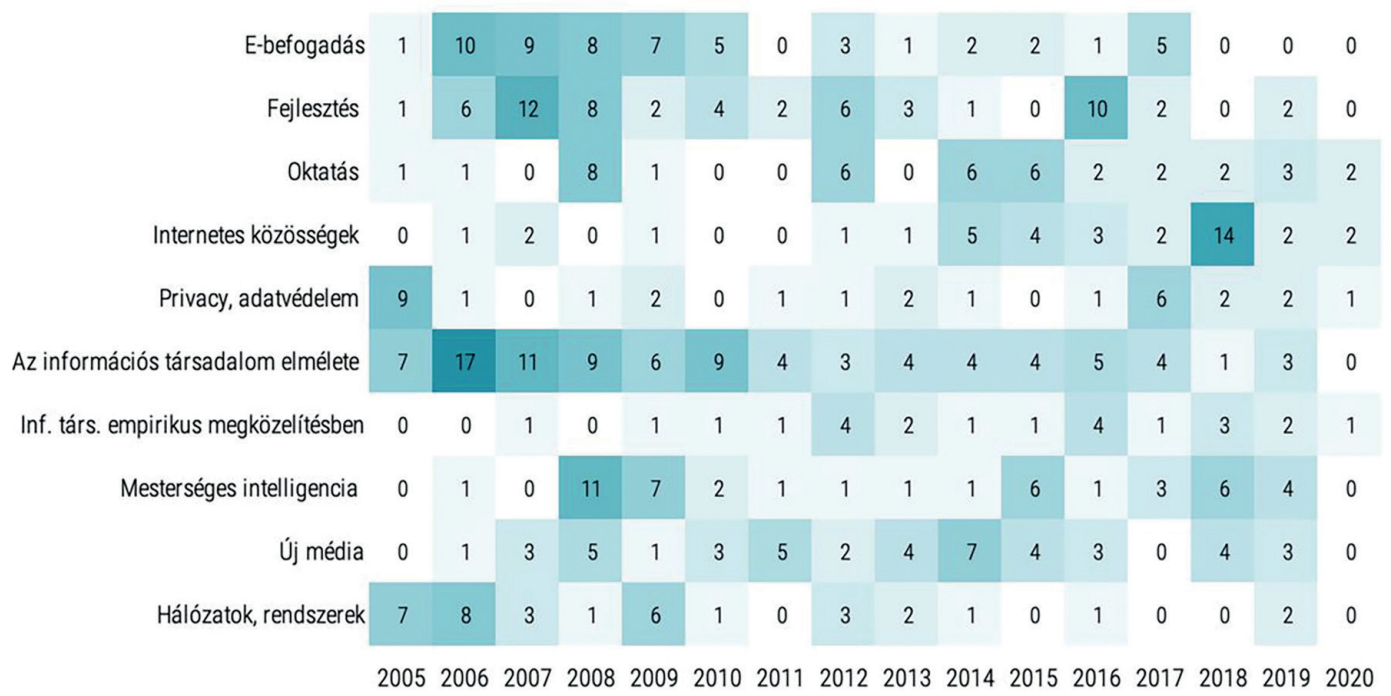

1. ábra: A topikok elhelyezkedése kétdimenziós térben

\section{A topikok viszonya}

Az alábbi, 2. ábra a pyLDAvis (Sievert és Shirley 2014) Python-csomag segítségével készült. A vizualizáció többdimenziós skálázást használ a topikok két dimenzióra vetítéséhez: ennek segítségével feltárható a topikok viszonya. Két topik tartalmi távolságát a körök középpontjainak távolsága mutatja meg. A körök mérete a topikokhoz tartozó szavak számával arányos.

Az ábrán szembetűnő a 10-es (Hálózatok, rendszerek) és 8-as (Mesterséges intelligencia) topik távolsága a többitől. Ez azt mutatja, hogy az egyébként is meglehetősen inhomogén, hálózatokat, fenntarthatóságot és innovációs klasztereket is tartalmazó, és a mesterséges intelligencia témájával foglalkozó tematikus csoport szóhasználatában távol helyezkedik el a többi topiktól. Nem annyira feltűnő, mégis észrevehető az oktatás (3-as topik) elkülönülése, amely szintén sajátos, ám az előző két topikhoz képest a többitől mégis kevésbé eltérő nyelvezetre utal. Nem meglepő módon a folyóirat fő fókuszát, és 
a legtöbb cikket tartalmazó 6-os, „az információs társadalom elmélete” topik helyezkedik el az ábra közepén, amelyhez némi átfedéssel kapcsolódik az ötös topik, mely az adatvédelem problematikájához köthető, amelyhez a középponttól távolodva kapcsolódik a fejlesztésekkel foglalkozó topik, míg ennek a láncolatnak a végén az új média és az ehhez kapcsolódó jövőképek állnak. Különálló egységet alkot az E-befogadás (1-es), az Internet és közösségek (4-es) és az Információs társadalom empirikus megközelítésben (7-es) topikja.

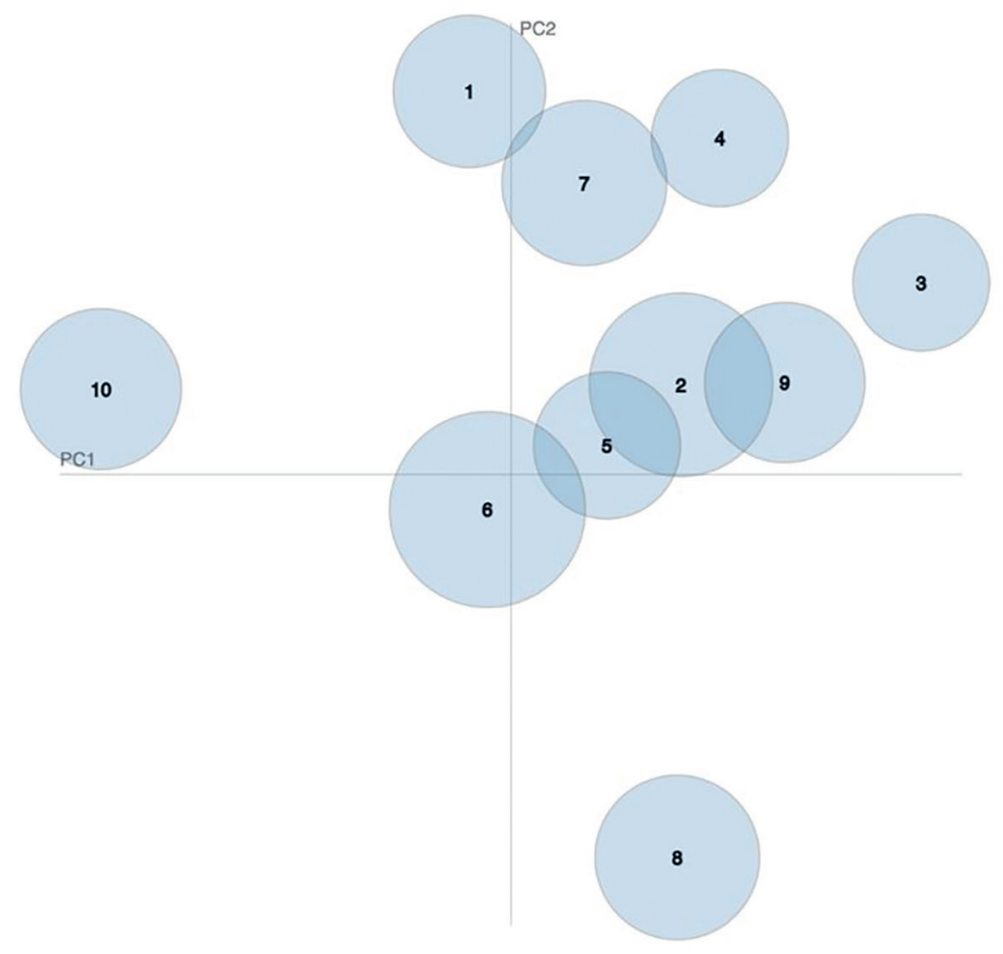

2. ábra: A topikok elhelyezkedése kétdimenziós térben

Megvizsgáltuk a feldolgozhatósági problémák miatt a cikkben nem szereplő tanulmányok absztraktjait is. Ez alapján a korábbi lapszámok is illeszkednek a topikmodellbe, elsősorban az információs társadalom elmélete és az információs társadalom empirikus megközelítésben topikokhoz tartozna sok tanulmány, de megjelenik az oktatás és a hálózatok, rendszerek topik is, legfőképp a két, 2003-ban megjelent tematikus számnak köszönhetően (a gazdaság témájával foglalkozott az 1., az oktatással pedig a 2. szám). A tanulmányban azonosított topikok közül még a Privacy, adatvédelem, az E-befogadás és az Internet és közösségek topikhoz tartozna több cikk a "kézi" besorolás szerint. Ellenben legfeljebb egy-két tanulmányban jellemző az általunk vélelmezett besorolás szerint a Fejlesztések és a Mesterséges intelligencia topik (ez utóbbi egy cikk esetén, a Szathmáry Eörssel készült interjú kapcsán merül fel (Kolin 2002)). 
Érdekes kérdésként adódik, hogy a 4. évfolyam dupla számában (2004/3-4) található élénk vita, amelyet Sükösd Miklós Totális medialitás és ökocídium című tanulmánya váltott ki (Sükösd 2003), és 16 válaszcikket generált, vajon befolyásolta volna-e a fenntarthatósággal foglalkozó, vagy más topikok súlyát.

\section{Szerzők és topikok kapcsolata}

A témák feltárása mellett a topikok azonosítása arra is lehetőséget ad, hogy megfigyeljük, a folyóirat szerzői jellemzően egy- vagy inkább többféle topikba írnak, társíthatók-e tipikus témák a szerzőkhöz ${ }^{22}$, az egy cikkel jelentkezők csoportosíthatók-e bizonyos topikokhoz, vagy inkább bizonyos témákhoz szólnak hozzá.

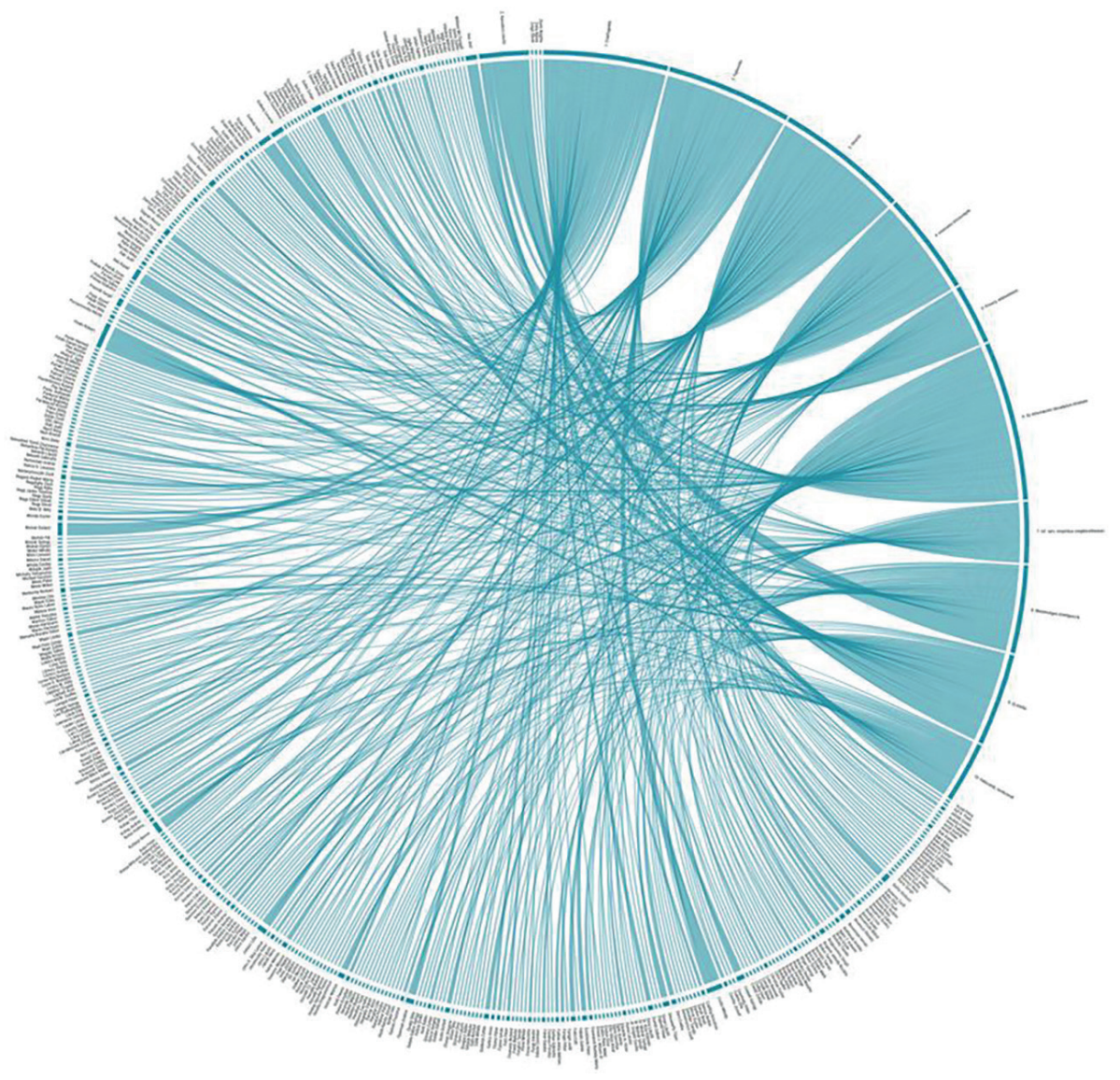

3. ábra: Az Információs Társadalom szerzőire jellemző topikok

\footnotetext{
$\overline{{ }^{22}}$ Téma alatt itt a topikmodell által azonosított nagyobb tematikus egységeket értjük. Természetesen előfordulhat, hogy egy szerző cikkei több topikba tartoznak úgy is, hogy hasonló témáról ír, csak esetleg különböző aspektusokból (például kutatási beszámolóként), vagy területének különböző alterületeiről, és így a modell különböző topikokba sorolta a cikkeit.
} 
Azt, hogy melyik szerző melyik topikba publikál, húrdiagram segítségével ábrázoltuk ${ }^{23}$, amelynek jobb oldalán, az óramutató járásával megegyező irányban találjuk a topikokat. A 3. ábrán az Információs Társadalom folyóirat feldolgozott cikkeinek összes szerzőjét láthatjuk, függetlenül attól, hogy hány cikket, és hogy egyedül vagy társszerzőkkel publikáltak. A folyóiratba összesen 407-en írtak önálló vagy társszerzős tanulmányt, de - ahogy az ábra is mutatja - a legtöbb, 316 szerző csak egyszer publikált az általunk elemzett 15 év alatt, és csak kevés olyan szerzőt tudunk azonosítani, akik számos tanulmányt írtak a folyóiratba. $\mathrm{Az}$ ábra célja átfogó képet adni a szerzők és topikok által rajzolt mintázatról. Interaktív, részletesen elemezhető és nagyítható verziója elérhető a következő linken: https://inftars.infonia.hu/inftars20.

Ahogy a fentiekben is írtuk, nem csak az általános mintázatra, hanem arra is kíváncsiak voltunk, megfigyelhető-e a szerzők topikokhoz tartozása, vagy inkább az a jellemző, a gyakrabban publikálók cikkeit különböző topikokba sorolta a modell. A következőkben tehát csak arra a 91 szerzőre fókuszálunk, akik kettő, vagy annál több cikket jelentettek meg a folyóiratban. A „több” elsősorban két-három cikket jelent, ugyanis viszonylag sok (összesen 71) szerző működött közre két vagy három tanulmánynál, míg jóval kevesebb, 10 szerző szerepel 4-6 publikációval.

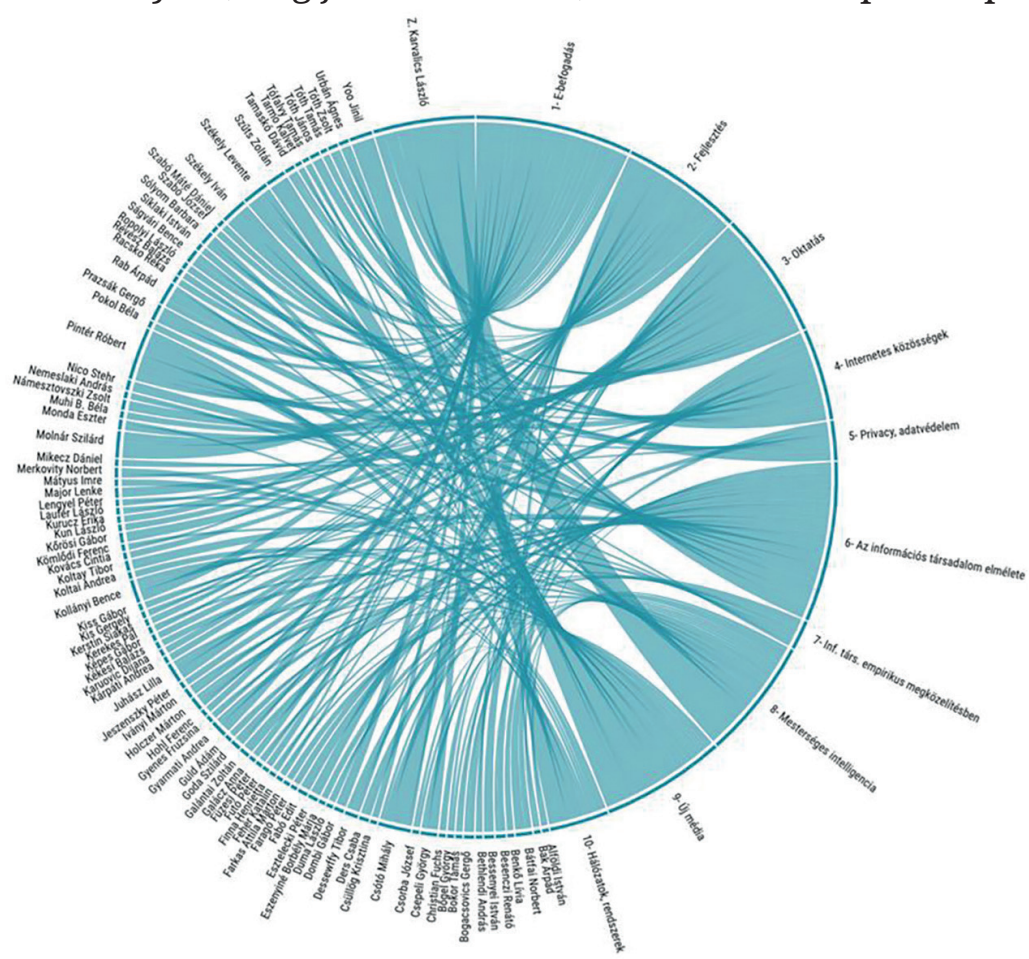

4. ábra: Az Információs Társadalom gyakran publikáló szerzőire legjellemzőbb topikok

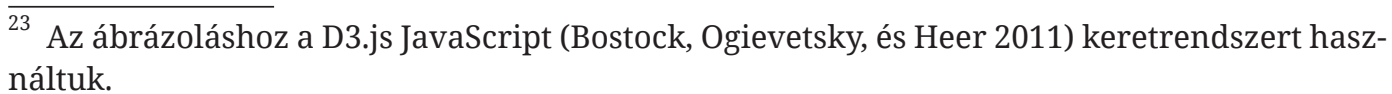


A következő néhány ábra a legtöbb tanulmányt jegyző szerzőkre leginkább jellemző topikokat hivatott bemutatni. Ők azok, akikre azt mondhatjuk, rendszeres szerzői a folyóiratnak. Kollányi Bence, Rab Árpád, és Yoo Jinil 7-7, Molnár Szilárd, Székely Iván és Székely Levente fejenként 8, Csótó Mihály öszszesen 10, Pintér Róbert pedig 16 cikk (társ)szerzője volt. A lista élén Z. Karvalics László, a lap alapítója, első főszerkesztője áll, aki 31 cikket jegyez.

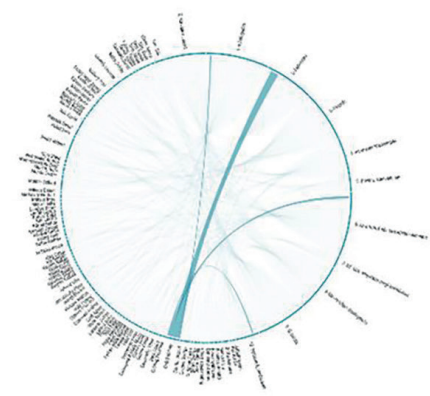

Csótó Mihály

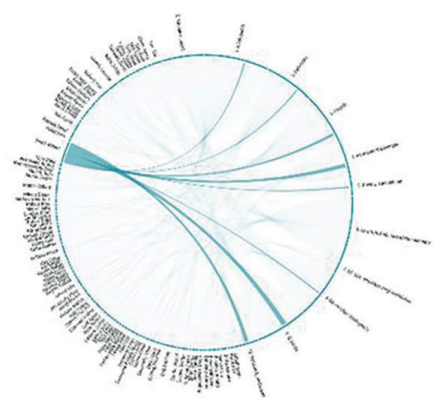

Pintér Róbert

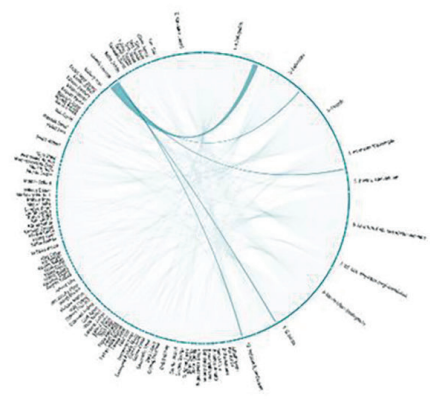

Székely Levente

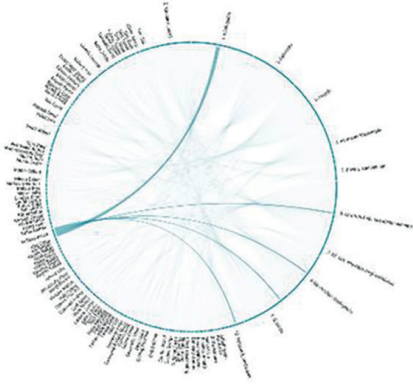

Kollánvi Bence

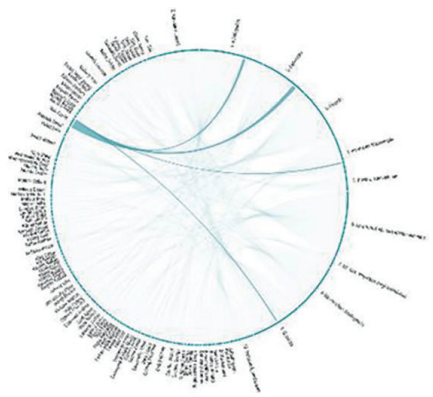

Rab Árpád

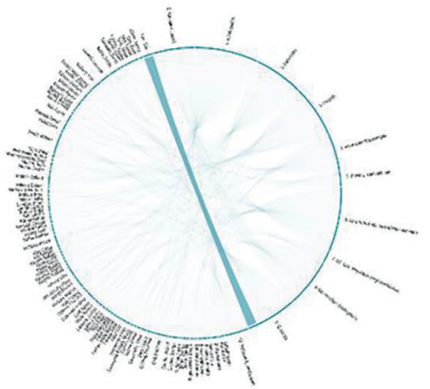

Yoo Jinil

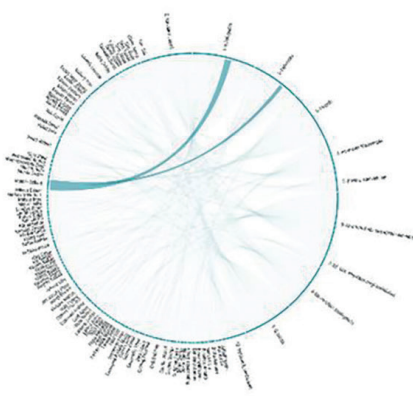

Molnár Szilárd

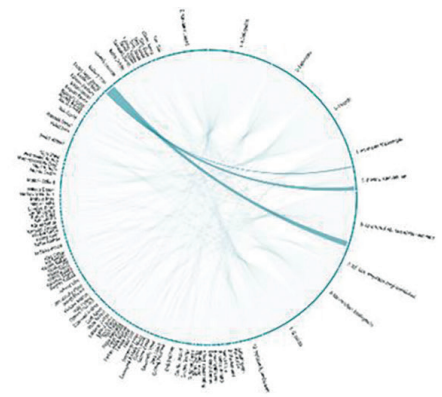

Székely Iván

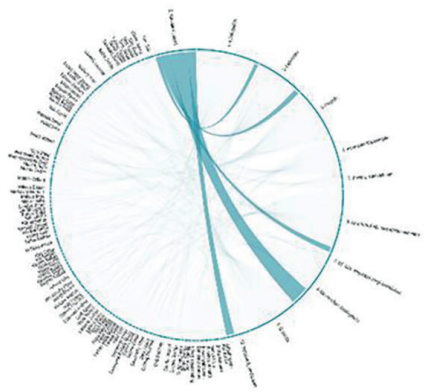

Z. Karvalics László

5. ábra: A legtöbbet publikáló szerzők cikkeire jellemző topikok

A legtöbbet publikáló szerzők közül Yoo Jinil az, akinek csak egy, az Új média topikba tartoznak cikkei. Molnár Szilárd az E-befogadás és a Fejlesztés topikba írt. Ide tartozik Csótó Mihály legtöbb tanulmánya is. Kollányi Ben- 
ce, Rab Árpád és Székely Levente esetén azt láthatjuk, hogy a cikkeik számos topikba tartoznak. Ők azok, akik többször, hangsúlyosabban foglalkoznak egy-egy témával, de nem csak egy témakörben publikálnak: Székely Levente ifjúságkutató esetén ez a kiemelt téma a generációs különbségekkel is fogllakozó E-befogadás, akárcsak Rab Árpádnál, akinél emellett a Fejlesztés topik is megjelenik. Kollányi Bence írásai pedig egy kivételével az internethasználathoz kapcsolódó topikokba tartoznak. Rab Árpádnál szintén az E-befogadás topik hangsúlyos a Fejlesztés topik mellett. Ki kell emelnünk Székely Ivánt, aki az általános $\mathrm{Az}$ információs társadalom elmélete topik mellett a specifikusabb Privacy, adatvédelem topikban is négy tanulmányt jegyez (társ)szerzőként. Ilyen értelemben a legsokoldalúbb szerző Pintér Róbert, akinek tanulmányai az információs társadalom empirikus megközelítéseit mutató és Az információs társadalom elmélete topik kivételével mindegyik topikban szerepelnek. Ezzel szemben Z. Karvalics László tanulmányait öt topikban találjuk meg, azokon belül is elsősorban a Mesterséges intelligencia topik dominál. Ezek a mintázatok alapvetően illeszkednek a felsorolt szerzők teljes publikációs listájából kirajzolódó profilba, az általuk művelt területekhez.

\section{Szerzői háló}

A tudományos munka egyik fokmérője nyilvánvalóan a publikálás (Molnár P., Pintér, és Tóth 2018). A legtöbb tudományterületen egyre több társszerzős cikk születik. Ahogy Sonnenwald (2007) írja, a társszerzőség két vagy több tudós között zajló interakció, melynek célja, hogy a szerzők közösen, egy célkitủzés mentén, könnyebben, hatékonyabban tudják megosztani a feladataikat, annak érdekében, hogy új tudás születhessen. Az alább látható hálózatot Gephi (Bastian, Heymann és Jacomy 2009) segítségével készítettük, és a hálózatot jellemző mutatókat is Gephiben számoltuk ki. Egy háló meghatározható szereplők (vagy node-ok, csomópontok) és a közöttük fennálló kapcsolatok (vagy linkek, élek) véges halmazaként (Wasserman és Faust 1994). A hálózat kirajzolásához a ForceAtlas2 algoritmust használtuk, az átláthatóság javítása érdekében a csomópontokat esetenként kézzel igazítottuk, de jelentős módosítás nem történt. Az algoritmus esztétikus elrendezésre törekszik, úgy müködik, mintha a csomópontok egymást taszító mágnesek, az élek pedig rugók lennének, tehát az egyes csomópontok, alhálózatok térbeli helyzete nem hordoz jelentést. Ennek segítségével az élek nem nyúlnak nagyon hosszúra, a csomópontok viszont jól szóródnak (Jacomy és mtsai. 2012).

Esetünkben a csomópontok egy-egy szerzőt jelölnek. A teljes gráf azokat a szerzőket jeleníti meg, akik legalább egy társszerzős cikket publikáltak a folyóiratban. Itt kell megemlítenünk, hogy az elemzett 460 cikk több mint háromnegyede, 76\%-a volt egy-, 17\%-a két, és összesen 7 százaléka három- vagy többszerzős, tehát a hálózat megközelítőleg az elemzett tanulmányok negyedére épül. 
Az adatok jellegéből fakadóan irányítatlan gráfot készítettünk. A csomópontok közötti élek vastagságát a közösen írt cikkek száma határozza meg. A hálózat interaktív verziója elérhető itt: https://inftars.infonia.hu/inftars20.

A legegyszerübb jellemzői egy hálózatnak a csomópontok és linkek száma, ez utal a hálózat méretére. A hálónk 225 csomópontból és 279 élből áll. Egy hálózat komponensekből épül fel. A gráf alapján jól látszik, hogy a hálót igen sok kis komponens és néhány nagyobb képezi. Számos szerzőpáros (diád), és szerzőhármas (triád) figyelhető meg. A három csomópontból álló alhálók létrejöhetnek két vagy három él kapcsolatából is, a négy csomópontból álló kis hálózatok a legtöbb esetben teljes gráfot képeznek, vagyis minden csomópont mindegyik másikkal össze van kötve. Az ilyen algráfokat klikkeknek nevezzük. A sok kicsi mellett három nagy komponens, algráf elkülönülése látható.

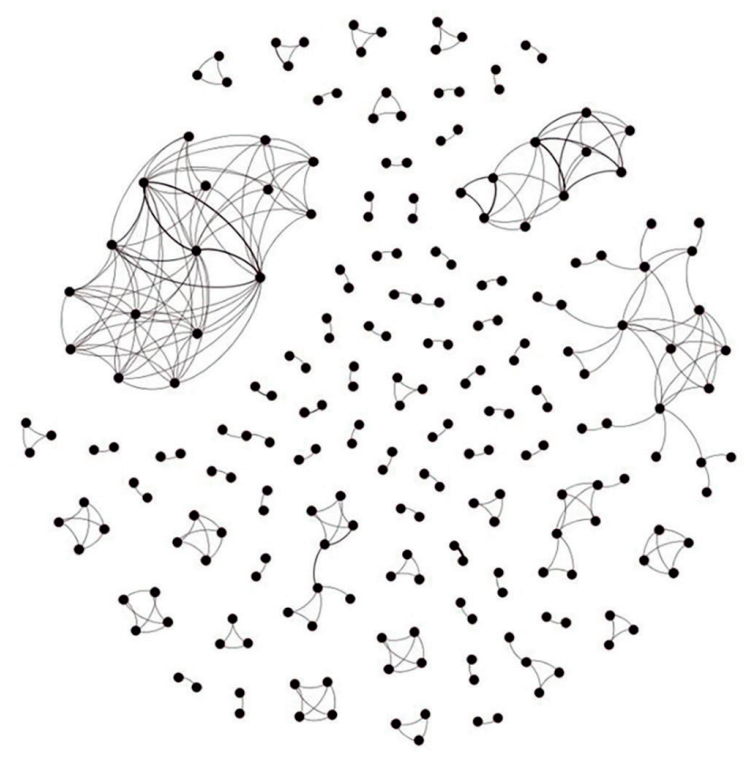

\begin{tabular}{|c|c|c|c|c|}
\hline Átlagos fokszám & Sürüség & Modularitás & $\begin{array}{c}\text { Átlagos } \\
\text { klaszterezettség }\end{array}$ & Átlagos úthossz \\
\hline 2,48 & 0,01 & 0,90 & 0,88 & 1,91 \\
\hline
\end{tabular}

6. ábra: A teljes társszerzőségi hálózat

A hálózatokat jellemezhetjük olyan mérőszámokkal, melyek annak szerkezetéről és általános tulajdonságairól nyújtanak információt. Mi az öt legtöbbet használt mutatóval, az átlagos fokszámmal, sürűséggel, modularitással, átlagos klaszterezettséggel, és az átlagos úthosszal jellemeztük a hálózatot, és a három külön vizsgált komponenst is. Fokszámnak nevezzük a csomópontokhoz tartozó éleket. Ebben az esetben a fokszám azt jelenti, hogy az adott szerző hány társszerzős cikket írt. A teljes hálóban az átlagos fokszám 2,5. A sűrüség az ösz- 
szekapcsoltság (connectivity) mértékét adja meg úgy, hogy a meglévő linkek számának arányát vizsgálja az adott hálózaton belüli lehetséges kapcsolatok maximális számához viszonyítva (Wasserman és Faust 1994). A szerzőháló esetében ez a szám nagyon alacsony, hiszen a hálónk sok kicsi komponensből áll. A modularitás azt mutatja meg, hogy a hálózatban egy hasonló jellemzőkkel bíró, de véletlenszerűen kapott hálózathoz képest mennyivel több kapcsolatot láthatunk (Bene 2016). A magas, közel 1-es modularitás a hálózat klikkesedését, szétesését mutatja, ami jól látszik a három nagyobb, és több kisebb csoportból. Ehhez hasonló információt mutat a klaszterezettség, mellyel azt mérjük, hogy a háló milyen szoros kapcsolatrendszerrel jellemezhető, mennyire jól kapcsolódik egymáshoz a csomópont szomszédsága. Ha az együttható 1, akkor azt mondhatjuk, hogy a csomópont szomszédsága teljesen összekapcsolódik (Tsolakidis és mtsai. 2012), vagyis a csúcs mindegyik szomszédja minden másikkal is kapcsolatban van. A fenti háló - összhangban a sürüségmutató kapcsán megfigyeltekkel - klikkesedik, nagyon széttöredezett. Megfigyelhető, hogy főként szerzői csoportok, szerzőpárosok közös munkája jellemző, az kevésbé, hogy A szerző írt B szerzővel cikket, B pedig C szerzővel, de C és A nem írtak együtt. A fentiek mellett egyéni szintű mérőszámokat is használhatunk a hálózatelemzés során, de mi ettől most eltekintünk, hiszen a teljes hálóra fókuszálunk.

A teljes szerzőségi hálózat esetében polarizált hálózatról beszélhetünk, mivel magas modularitás és klaszterezettség, valamint nem túl magas úthossz jellemzi. A polarizált hálózat egymástól jól elkülöníthető csoportokra oszlik, csak a csoportokon belül magas a kohézió, azaz belül megfigyelhetők kapcsolatok, közöttük viszont nemigen (Bene 2016).

A következőkben a három óriáskomponensként definiálható szerzői hálózatot nézzük meg részletesebben.

Az első alháló merőben eltér a másik kettőtől, mivel az átlagos úthossza jóval nagyobb, klaszterezettsége pedig jóval kisebb a másik két hálózaténál. Ebben az esetben diffúz hálózatról beszélhetünk, itt nincs egy konkrét szerzői közösség, és a távolságok igen nagyok (Bene 2016). A másik két hálózat ezzel szemben kisvilág-tulajdonságú, azaz az átlagos távolság a hálózaton belül a hálózat méretéhez képest kicsi (Bene 2016; Travers és Milgram 1969). Míg az első hálóban sokan csak szegről-végről tartoznak össze (Faragó Judit és Futó Péter például a hálózat két igen távoli pontján található), addig a másik két gráf sokkal sürübb: szinte mindenki publikált közösen mindenkivel. Ez utóbbi két hálózat markáns megjelenése leginkább annak köszönhető, hogy az egyéni szerzőség, mint azt láthattuk, igen jellemző a folyóiratban.

Az első alháló a legnépesebb: 22 szerző és 35 él alkotja. Kiemelten fontos szereplő Z. Karvalics László, Rab Árpád, Csótó Mihály, Székely Levente, Juhász Lilla, Molnár Szilárd és Borovitz Tamás: ők azok, akik magas fokszámmal jellemezhetőek, 5-6 másik szerzővel publikáltak közösen. A gráfban pirossal jelöltük a folyóirat jelenlegi és egykori főszerkesztőit. Erre a hálóra, szemben a többivel az is jellemző, hogy nincs olyan szerzőpár, amely igen gyakran ír egymással közösen. 


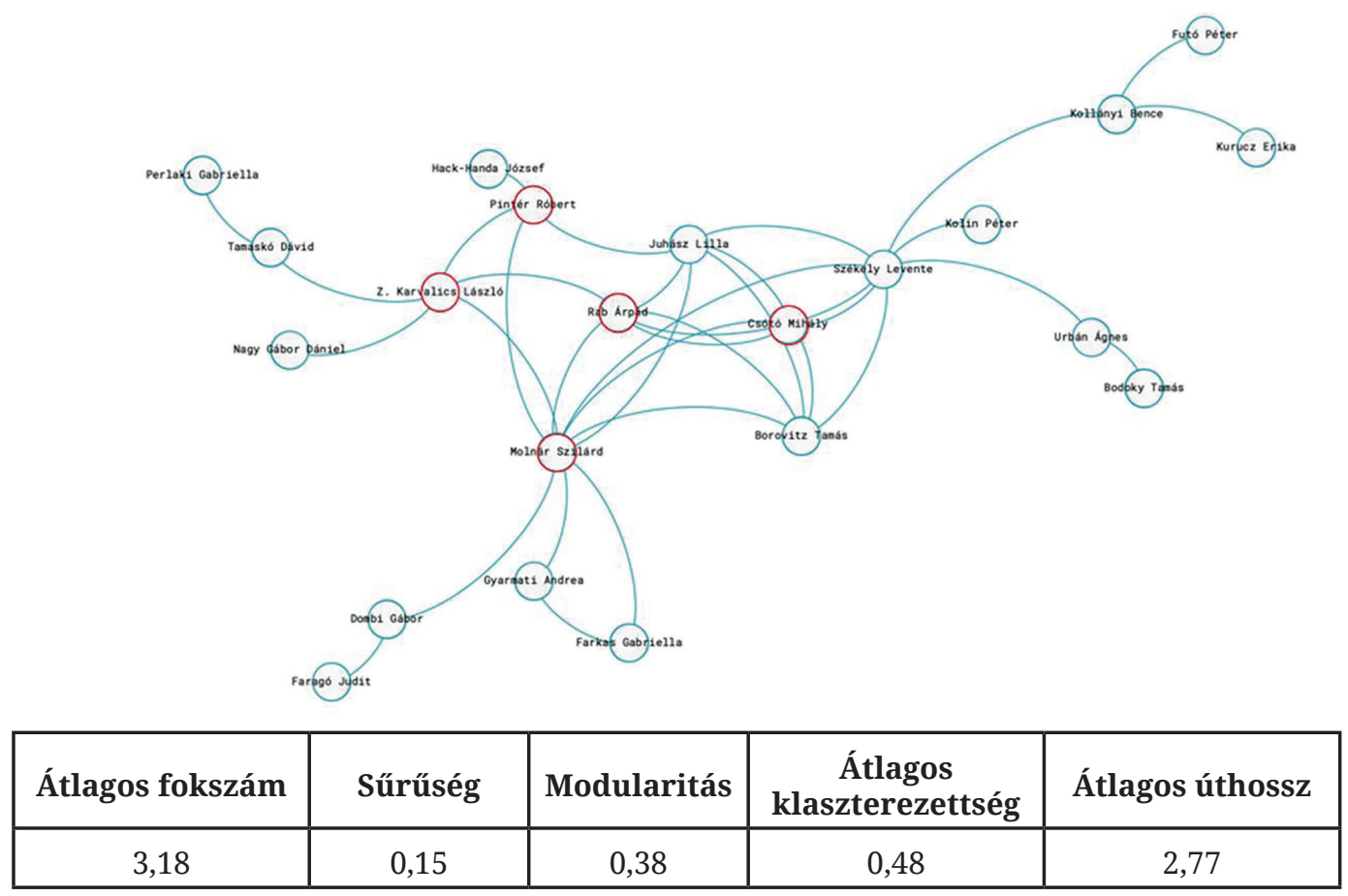

7. ábra: Első szerzői algráf

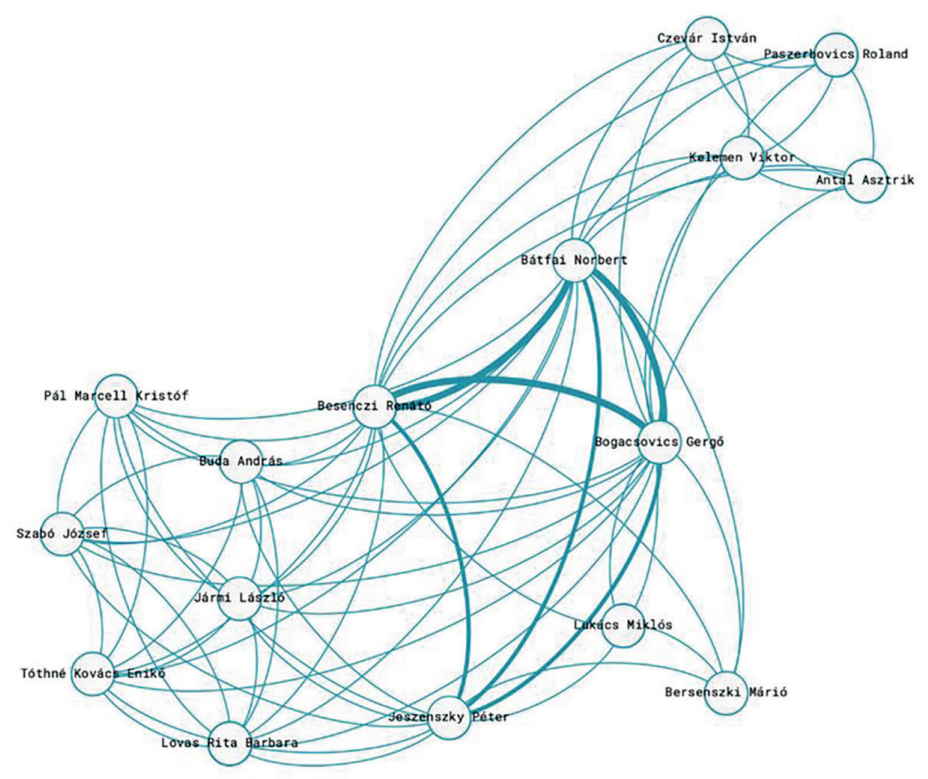

\begin{tabular}{|c|c|c|c|c|}
\hline Átlagos fokszám & Sürűség & Modularitás & $\begin{array}{c}\text { Átlagos } \\
\text { klaszterezettség }\end{array}$ & Átlagos úthossz \\
\hline 9 & 10,13 & 0,15 & 0,90 & 1,4 \\
\hline
\end{tabular}

8. ábra: Második szerzői algráf 
Míg a másik két hálózat egy-egy téma köré szerveződő kutatócsoportokat és egyegy cikk társszerzőit rajzolja ki, addig erre a hálózatra azt mondhatjuk, ez „valódi” társszerzőségi hálózatot mutat, különböző kutatói együttműködésekből állva össze. Ezt jelzi az alacsonyabb átlagos fokszám és sürüség, és a nagyobb átlagos úthossz is. Ez a háló gyakorlatilag a lap mögött álló kutatói műhely, a BMEITTK és annak tágabb környezete, amelynek magja az intézet megszünése után is aktív, olykor közösen publikáló hálózat maradt (a hálózat egymástól távoli elemei sok esetben a központi szerzők különböző egyéb affiliációihoz köthetők).

A második és harmadik algráfon látható egy gyakran együtt publikáló szerzői mag: a második, csupán 16 csúcsból, de 72 élből álló hálóban Bátfai Norbert, Besenczi Renátó és Boganovics Gergő triumvirátusa emelendő ki. Ez a hálózat valójában a Debreceni Egyetem Informatikai Karához köthető, és legfőképpen a szerzők által közösen, a Videojáték és e-sport tematikus lapszámba írt három tanulmánynak köszönhetően rajzolódik ki. A téma többrétű kutatása mellett a DE saját e-sport szakosztályt is müködtet.

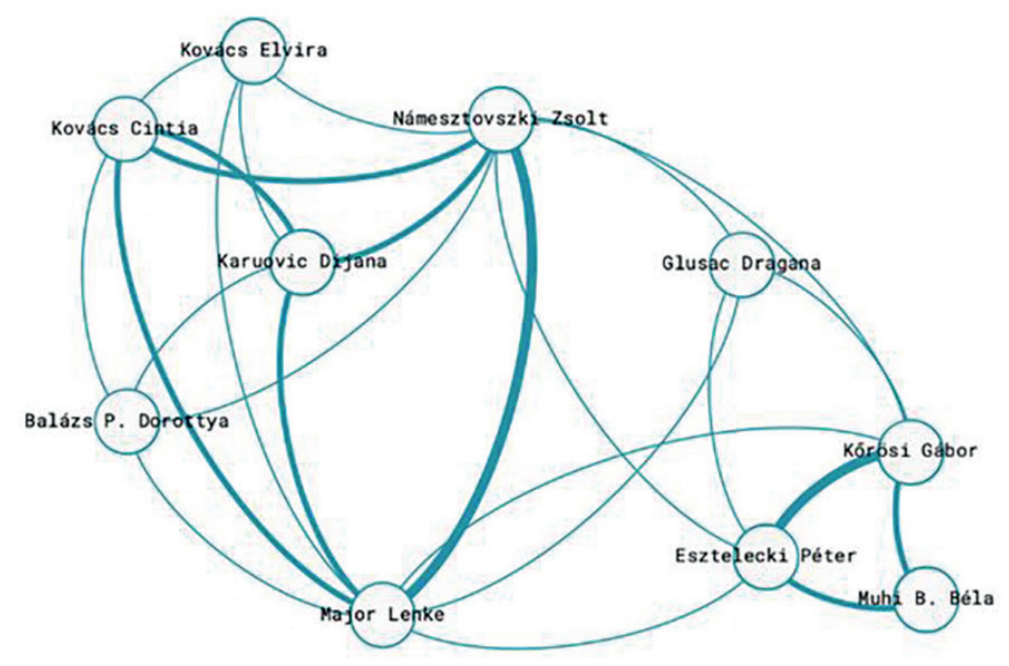

\begin{tabular}{|c|c|c|c|c|}
\hline Átlagos fokszám & Sürúség & Modularitás & $\begin{array}{c}\text { Átlagos } \\
\text { klaszterezettség }\end{array}$ & Átlagos úthossz \\
\hline 5 & 7,2 & 0,28 & 0,83 & 1,53 \\
\hline
\end{tabular}

9. ábra: Harmadik szerzői algráf

A harmadik szerzőcsoport áll a legkevesebb csúcsból. Ide 10 szerző tartozik, akiket 25 él köt össze. Fokszám tekintetében ez a legkiegyensúlyozottabb gráf. A legtöbb közös publikációt jegyző két szerzőpáros három-három közös tanulmánnyal Major Lenke és Námesztovszki Zsolt, valamint Esztelecki Péter és Kőrösi Gábor. Az algráf az e-learning, blended learning témája köré szerveződik, ugyanis a gráf az Újvidéki Egyetemhez és a Szegedi Tudományegyetemhez kötődő, oktatás-informatikával foglalkozó kutatók közös tanulmányait mutatja. 


\section{Összefoglalás}

Munkánk során az Információs Társadalom folyóirat elmúlt 15 évének tanulmányait elemezzük azzal a céllal, hogy feltárjuk, milyen témák köré szerveződtek a folyóiratban megjelenő publikációk az évek során, így képet kapva arról, milyen kérdések foglalkoztatták a hazai információs társadalommal foglalkozó kutatókat. Topikelemzés segítségével 10 területet azonosítottunk.

A legmarkánsabb, illetve a topikok viszonyában is központi témaként jelenik meg az információs társadalom általános elméleti feldolgozása, a lap eredeti célkitűzésének megfelelően. Ezeken túl olyan, az elemzett időszakban rendszeresen jelen lévő témák kerültek azonosításra, mint az internethasználati különbségek, az oktatás vagy az adatvédelem vagy a mesterséges intelligencia. A felsorolt témák általában az információs társadalommal foglalkozó irodalom kiemelt és folyamatosan nagy érdeklődést kiváltó területei. A lap második évtizedében tetten érhető néhány topik hangsúlyosabbá válása, melyek elsősorban az információs társadalom egy-egy újabb jellegzetességét dolgozzák fel (új média, internet és közösségek), míg az empirikus kutatások kapcsán ez valószínüleg annak köszönhető, hogy számos szakterületen egyre inkább szaporodtak az e jelenségeket feltáró kutatások, illetve ennek folyományaként a laphoz benyújtott empirikus munkák. A topikelemzés két átfogóbb megközelítést is azonosított, amelyek több tématerületet is egy topik részévé tettek. Az egyik ilyen a fejlesztés, vagyis olyan témák (például e-közigazgatás, okosváros) amelyekről a tanulmányok elsősorban aktív beavatkozási fókusszal és jövőorientációval írnak. A másik megközelítés kulcsa a hálózatok és a rendszerszemlélet, amely egyaránt jellemző az innovációs rendszerekről és a fenntartható információs társadalomról szóló tanulmányokra. A topikok időbeli megjelenési változatosságával kapcsolatban elmondható, hogy nincs olyan közöttük, amely az idők során egyformán kiemelt szerepet kapna, illetve a legtöbb évben a topikok súlya közel hasonló. Mindezek mellett a szerkesztőség a tematikus számokkal jelentősen alakította a feldolgozott témák körét, alakította a diskurzust.

A legtöbb cikket jegyző szerzők a lapot alapító egyetemi mühely munkatársai közül kerülnek ki. Ebben nagy szerepet játszik, hogy ezek a szerzők a tanulmányaik mellett számos konferenciabeszámolót, recenziót, projektbeszámolót is jegyeznek (lényegében ez a szerzői kör alkotja a laphoz kapcsolható társzerzői hálózatok közül is a legnagyobbat). Mellettük nagyon sok szerző publikált egyszer a lapban, a folyóirat széles szerzői kört mozgatott meg az évek során.

A tanulmányok témái mellett a folyóiratba publikáló szerzőkre jellemző topikokat, valamint a szerzők társszerzőségi hálózatát is megvizsgáltuk. Eredményeink alapján azt mondhatjuk, a folyóiratba publikáló szerzők hálózata töredezett, a legtöbb szerző csak a közvetlen társszerzőivel van kapcsolatban. Azonosítható azonban a teljes hálózaton belül három elkülönülő algráf, ezek egyike a folyóirat szellemi műhelyeként szolgáló BME-ITTK-ból kiinduló kutatói közösség, de a másik két csoport is jellemzően egy-egy intézmény körül alakult ki. 


\section{A folyóiratból idézett cikkek}

Agre, Philip E. „Az arcunk nem vonalkód (érvek a nyilvános helyeken elhelyezett automatikus arcfelismerő berendezések használata ellen)”. Információs Társadalom, V. évf., 2. szám, 2005, 114-36. old. DOI: https://doi.org/10.22503/inftars.V.2005.2.7

Alföldi István. „Az értelmiség szerepe, felelőssége”. Információs Társadalom, VIII. évf., 4. szám, 2008, 12-14.old. DOI: https://doi.org/10.22503/inftars.VIII.2008.4.2

András Ferenc. „Zsuzsanna Kondor: Embedded Thinking”. Információs Társadalom, VIII. évf., 4. szám, 2008, 136-39.old. DOI: https://doi.org/10.22503/inftars.VIII.2008.4.16

Asheim, Bjorn T., és Lars Coenen. „Tudásbázisok és regionális innovációs rendszerek: skandináviai klaszterek összehasonlítása”. Információs Társadalom, 6. évf., 3. szám, 2006, 114-41.old. DOI: https://doi.org/10.22503/inftars.VI.2006.3.7

Balkányi Péter és Orbán Zsolt. „Virtuális információk a fizikai térben: a kiterjesztett valóság jövőképe”. Információs Társadalom, XI. évf., 1-4. szám, 2011, 64-80.old. DOI: https://doi. org/10.22503/inftars.XI.2011.1-4.4

Bányai Fanni, Zsila Ágnes, Demetrovics Zsolt, és Király Orsolya. „A problémás videojátékhasználat újabb elméleti és gyakorlati megközelítései”. Információs Társadalom, XVIII. évf., 1. szám, 2018, 93-106.old. DOI: https://doi.org/10.22503/inftars.XVIII.2018.1.6

Bene Márton. „Kommunikációs hálózatok és politikai közösség”, Információs Társadalom, 25. évf., 1. szám, 2016, 48-73.old. DOI: https://doi.org/10.22503/inftars.VIII.2008.2.2

Bernát Anikó, Fábián Zoltán, Galácz Anna, és Ságvári Bence. „Esély és digitális írástudás: médiafogyasztási és digitális eszközhasználati státuscsoportok Magyarországon”. Információs Társadalom, VIII. évf., 2. szám, 2008, 110-33.old. DOI: https://doi.org/10.22503/ inftars.VIII.2008.2.11

Bessenyei István. „Napló a hálózati tanításról”. Információs Társadalom, V. évf., 3. szám, 2005, 47-62.old. DOI: https://doi.org/10.22503/inftars.V.2005.3.4

Bessenyei István és Tóth Zsolt. „E-learning: a NETIS-projektben szerzett tapasztalatok”. Információs Társadalom, VIII. évf., 3. szám, 2008, 31-40.old. DOI: https://doi.org/10.22503/ inftars.VIII.2008.3.3

Borsi Balázs. „A visegrádi országok perspektívája az Európai Kutatási és Innovációs Térségben”. Információs Társadalom, VI. évf., 3. szám, 2006, 54-70.old. DOI: https://doi. org/10.22503/inftars.VI.2006.3.4

Bőgel György. „Merre tart a K+F? A nemzetközi munkamegosztás átrendeződése a kutatás és a fejlesztés területén”. Információs Társadalom, VI. évf., 3. szám, 2006, 71-83.old.

DOI: https://doi.org/10.22503/inftars.VI.2006.3.5

Csedő Zoltán, Tóth Tamás, Égler András, és Sára Zoltán. „Online képzési stratégiák és módszerek a közszolgálati továbbképzésekben”. Információs Társadalom, XIV. évf., 1. szám, 2014, 9-28.old. DOI: https://doi.org/10.22503/inftars.XIV.2014.1.1

Csepeli György. „Régi és új szociálpolitika”. Információs Társadalom, VI. évf., 2. szám, 2006, 15-22.old. DOI: https://doi.org/10.22503/inftars.VI.2006.2.3

Csepeli György. „A szegénység a digitális korban”. Információs Társadalom, XVII. évf., 2. szám, 2017, 48.old. https://doi.org/10.22503/inftars.XVII.2017.2.3

Csótó Mihály. „Zöldebb, mint hinnénk?” Információs Társadalom, IX. évf., 2. szám, 2009, 99101.old. DOI: https://doi.org/10.22503/inftars.IX.2009.2.8 
Ders Csaba. „Egy Okos Pécs Felé”. Információs Társadalom, XVII. évf., 3. szám, 2017, 23-82.old. DOI: https://doi.org/10.22503/inftars.XVI.2016.3.2

Duma László, és Monda Eszter. „Táblagépek oktatási eszközként való bevezetésének hatása infotársadalom szcenáriók”. Információs Társadalom, XII. évf., 3. szám, 2012, 15-49.old. DOI: https://doi.org/10.22503/inftars.XII.2012.3.2

Egres Dorottya. „Virtuális vitatér - A Paks 2 polilógus hyperlinkhálózatának elemzése”. Információs Társadalom, XX. évf., 1. szám, 2020, 50-71.old. DOI: https://doi.org/10.22503/ inftars.XX.2020.1.3

Eranus Eliza, Lengyel György és Siklós Viktória. „A cserénfai kísérlet - két év múlva”. Információs Társadalom, VI. évf., 2. szám, 2006, 109-22.old. DOI: https://doi.org/10.22503/ inftars.VI.2006.2.11

Farkas Gabriella, Gyarmati Andrea, és Molnár Szilárd. „Az idősödő társadalom gazdasági és társadalmi kihívásai Magyarországon”. Információs Társadalom, IX. évf., 4. szám, 2009, 7-31.old. DOI: https://doi.org/10.22503/inftars.IX.2009.4.1

Fehér Katalin. „Metamintázatok az új médiában”. Információs Társadalom, XIII. évf., 1. szám, 2013, 24-30.old. DOI: https://doi.org/10.22503/inftars.XIII.2013.1.2

Fromann Richárd, és Damsa Andrei. „Videojátékoktól a munka világáig-játékostipológiák és munkahelyi motivációk”. Információs Társadalom, XVIII. évf., 1. szám, 2018, 18-25.old. DOI: https://doi.org/10.22503/inftars.XVIII.2018.1.2

Fuchs, Christian. „A fenntartható információs társadalom ideológiai tájképe 1. rész”. Információs Társadalom, IX. évf., 2. szám, 2009a, 7-19.old. DOI: https://doi.org/10.22503/ inftars.IX.2009.2.1

Fuchs, Christian. „A fenntartható információs társadalom ideológiai tájképe 2. rész”. Információs Társadalom, IX. évf., 3. szám, 2009b, 27-52.old. DOI: https://doi.org/10.22503/ inftars.IX.2009.3.2

Futó Péter és Kollányi Bence. „Az Európai Unió e-Inclusion programja és a magyarországi helyzet”. Információs Társadalom, VII. évf., 3. szám, 2007, 115-24.old. DOI: https://doi. org/10.22503/inftars.VII.2007.3.7

Galácz Anna és Ságvári Bence. „Digitális döntések és másodlagos egyenlőtlenségek: a digitális megosztottság új koncepciói szerinti vizsgálat Magyarországon.” Információs Társadalom, VIII. évf., 3. szám, 2008, 37-52.old. DOI: https://doi.org/10.22503/inftars.VIII.2008.2.3

Glózer Rita és Guld Ádám. „Új média-új típusú sztárok? A YouTube magyar hírességei”. Információs Társadalom, XV. évf., 2. szám, 2015, 34-54.old. DOI: https://doi.org/10.22503/ inftars.XV.2015.2.3

Gyarmati Andrea. „Az aktivitás szerepe az IKT időskori felhasználásában”. Információs Társadalom, IX. évf., 4. szám, 2009, 32-48.old. DOI: https://doi.org/10.22503/inftars.IX.2009.4.2

Hack-Handa József, és Pintér Róbert. „Generációs különbségek a magyar médiafogyasztásban”. Információs Társadalom, XV. évf., 2. szám, 2015, 7-17.old. DOI: https://doi.org/10.22503/ inftars.XV.2015.2.1

Hohl Ferenc. „A teleházak árképzésének és földrajzi elhelyezkedésének összefüggései”. Információs Társadalom, VI. évf., 2. szám, 2006, 98-108.old. DOI: https://doi.org/10.22503/ inftars.VI.2006.2.10

Hronszky Imre. „Két megjegyzés az innovációról”. Információs Társadalom, VI. évf., 3. szám, 2006, 9-28.old. DOI: https://doi.org/10.22503/inftars.VI.2006.3.1 
Hülber László. „Az online projektmunka és megvalósításának eszközei”.Információs Társadalom, XII. évf., 3. szám, 2012, 78-91.old. DOI: https://doi.org/10.22503/inftars.XII.2012.3.5

Iványi Márton. „»Kiber-szubkultúrák 1«: internet és radikalizmus”. Információs Társadalom, XIV. évf., 2. szám, 2014, 45-65.old. DOI: https://doi.org/10.22503/inftars.XIV.2014.2.3

Iványi Márton. „A számítógép-alapú kommunikáció és a digitális médiagazdaság állami és nagyvállalati perspektívái.” Információs Társadalom, XIX. évf., 2. szám, 2019, 35-51.old. DOI: https://doi.org/10.22503/inftars.XIX.2019.2.3

Jedlowski, Paolo. „Az emlékezet szociológiája”. Információs Társadalom, VIII. évf., 4. szám, 2008, 100-114.old. DOI: https://doi.org/10.22503/inftars.VIII.2008.4.13

Jinil, Yin. „A koreai információs társadalom kultúra-specifikus jelenségei”. Információs Társadalom, XIV. évf., 3. szám, 2014, 28-43.old. DOI: https://doi.org/10.22503/inftars. $\underline{\text { XIV.2014.3.3 }}$

Juhász Lilla. „E-közigazgatás Európában: fókuszban a közigazgatás racionalizálása és az állampolgár”. Információs Társadalom, VII. évf., 1. szám, 2007, 17-30.old. DOI: https://doi. org/10.22503/inftars.VII.2007.1.2

Kalvet, Chris Sadler-Tarmo. „Információs társadalmi ismeretek tanulása a gyakorlatban”. Információs Társadalom, VIII. évf., 3. szám, 2008, 126-36.old. DOI: https://doi.org/10.22503/ inftars.VIII.2008.3.8

Karácsony András. „Konzervatív beállítódás az »információ« korában (adottságok mint lehetőségek)”. Információs Társadalom, VI. évf., 4. szám, 2006, 18-27.old. DOI: https://doi. org/10.22503/inftars.VI.2006.4.3

Kolin Péter. „Az evolúciólegújabblépései? Interjú Szathmáry Eörssel”. Információs Társadalom, II. évf., 2. szám, 2002, 88-96.old. DOI: https://doi.org/10.22503/inftars.II.2002.2.6

Krasznai András, és Szakolyi Zsófia. „Hogyan teljesítik az önkormányzatok az e-ügyintézésre vonatkozó törvényi elõírásokat? - A GVOP-pályázatok hatása”. Információs Társadalom, VII. évf., 1. szám, 2007, 47-60.old. DOI: https://doi.org/10.22503/inftars.VII.2007.1.5

Kun László. „Városfejlesztés és okos városok mutatószámoktükrében”.Információs Társadalom, XVII. évf., 3. szám, 2017, 157-64.old. https://doi.org/10.22503/INFTARS.XVI.2016.3.8

Levy, Pierre. „Az értelmiség új felelőssége a kommunikáció korában”. Információs Társadalom, VIII. évf., 4. szám, 2008, 6-11.old. DOI: https://doi.org/10.22503/inftars.VIII.2008.4.1

Mihalik Judit. „»Újra megtanultam önmagamban lenni«, avagy négy teljes hét Facebook nélkül”. Információs Társadalom, XX. évf., 1. szám, 2020, 95.old. https://doi.org/10.22503/ inftars.XX.2020.1.5

Mikecz Dániel. „Az internet szerepe az alternatív mozgalmak dinamikájában”. Információs Társadalom, VII. évf., 3. szám, 2007, 70-82.old. DOI: https://doi.org/10.22503/inftars. VII.2007.3.4

Mikecz Dániel. „Komoly tét és söralátét”. Információs Társadalom, IX. évf., 3. szám, 2009, 1035.old. DOI: https://doi.org/10.22503/inftars.IX.2009.3.7

Molnár Szilárd. „A megrekedt magyar modernizáció kiútkeresése a sokrétű digitális megosztottság útvesztőjéből”. Információs Társadalom, XVII. évf., 2. szám, 2017, 30-47.old. https://doi.org/10.22503/inftars.XVII.2017.2.2

Monda Eszter. „eLearning sikertényezők - Egy eLearning projekt elemzése”. Információs Társadalom, XIV. évf., 1. szám, 2014, 29-51.old. DOI: https://doi.org/10.22503/inftars. $\underline{\text { XIV.2014.1.2 }}$ 
Námesztovszki Zsolt, Dragana Glušac, Esztelecki Péter, Kőrösi Gábor, és Major Lenke. „Tapasztalatok három saját készítésű MOOC kapcsán - a tervezéstől a kiértékelésig”. Információs Társadalom, XV. évf., 3. szám, 2015, 63-84.old. https://doi.org/10.22503/inftars. XV.2015.3.4

Nyíri Kristóf. „Konzervatívnak lenni az internet korában”. Információs Társadalom, VI. évf., 4. szám, 2006, 9-17.old. DOI: https://doi.org/10.22503/inftars.VI.2006.4.2

Ollé János. „A tudás alapú társadalom iskolája”. Információs Társadalom, XII. évf., 3. szám, 2012, 7-14.old. DOI: https://doi.org/10.22503/inftars.XII.2012.3.1

Pete Krisztián. „A társadalmi konvenciók természetéről”. Információs Társadalom, VII. évf., 4. szám, 2008, 73-99.old. DOI: https://doi.org/10.22503/inftars.VIII.2008.4.12

Pintér Róbert. „Társadalmi informatika - információs társadalom mindenkinek?” Információs Társadalom, VI. évf., 4. szám, 2006, 134-42.old. DOI: https://doi.org/10.22503/inftars. VI.2006.4.14

Pintér Róbert. „Blogok és wikik: a felhasználó által létrehozott tartalmak úttörő”. Információs Társadalom, VIII. évf., 1. szám, 2008a, 10-19.old. DOI: https://doi.org/10.22503/inftars. VIII.2008.1.2

Pintér Róbert. „Információs társadalmi tanulmányok a gyakorlatban - bemutatkozik a NETISprojekt”. Információs Társadalom, VIII. évf., 3. szám, 2008b, 7-17.old. DOI: https://doi. org/10.22503/inftars.VIII.2008.3.1

Pintér Róbert. „Az internetes választáskutatástól a netnográfiáig”. Információs Társadalom, IX. évf., 9. szám, 2009, 106-9.old. DOI: https://doi.org/10.22503/inftars.IX.2009.3.8

Pintér Róbert. „IPhone vs. Android”. Információs Társadalom, X. évf., 3-4. szám, 2010, 61-68. old. DOI: https://doi.org/10.22503/inftars.X.2010.3-4.7

Pintér Róbert. „Az okostelefonok terjedése Magyarországon”. Információs Társadalom, XI. évf., 1-4. szám, 2011, 48-63.old. DOI: https://doi.org/10.22503/inftars.XI.2011.1-4.3

Pintér Róbert. „A jövő rajtunk múlik! WTF?!” Információs Társadalom, XVIII. évf., 3-4. szám, 2018, 152-59.old. https://doi.org/10.22503/inftars.XVIII.2018.3-4.8

Polyák Gábor. „Technológiai determinizmus a kommunikáció szabályozásában1”. Információs Társadalom, XI. évf., 1. szám, 2011, 31-47.old. DOI: https://doi.org/10.22503/inftars. $\underline{X I .2011 .1-4.2}$

Rab Árpád. „A magyarországi idős korosztály információs írástudása és motivációi”. Információs Társadalom, IX. évf., 4. szám, 2009, 49-54.old. DOI: https://doi.org/10.22503/inftars.IX.2009.4.3 Rátai Balázs és Szemes Balázs. „Szellemi közjavak: a nyílt forrású szellemi alkotások jövője”. Információs Társadalom, VIII. évf., 1. szám, 2008, 35-44.old. DOI: https://doi.org/10.22503/ inftars.VIII.2008.1.4

Särav, Sandra, Tanel Kerikmäe, és Kasper Ágnes. „Az e-polgárság mint a virtuális migráció eszköze Észtországban”. Információs Társadalom, XVI. évf., 2. szám, 2016, 8-31.old.

DOI: https://doi.org/10.22503/inftars.XVI.2016.2.1

Sólyom Barbara. „Általános iskolások okostelefon-használati szokásai 2016-ban”. Információs Társadalom, XVI. évf., 1. szám, 2016, 29-45.old. DOI: https://doi.org/10.22503/inftars. $\underline{\text { XVI.2016.1.2 }}$

Sólyom Barbara. „Digitális esélyegyenlőség-Az eMultiCoop Szociális Szövetkezet”. Információs Társadalom, XVII. évf., 2. szám, 2017, 78-90.old. DOI: https://doi.org/10.22503/inftars. $\underline{\text { XVII.2017.2.6 }}$ 
Stoffa Veronika. „Az animáció szerepe az elektronikus tankönyvekben”. Információs Társadalom, VIII. évf., 3. szám, 2008, 113-25.old. DOI: https://doi.org/10.22503/inftars. VIII.2008.3.7

Sulyok Judit. „Mi újság a médiában?: Az írott sajtó szerepe az imázs formálásában egy turisztikai desztináció, a Balaton példáján keresztül”. Információs Társadalom, XII. évf., 2. szám, 2012, 105-21.old. DOI: https://doi.org/10.22503/inftars.XII.2012.2.7

Sükösd Miklós. „Totális medialitás és ökocídium”. Információs Társadalom, III. évf., 3-4. szám, 2003, 131-46.old. DOI: https://doi.org/10.22503/inftars.III.2003.3-4.8

Szabella Olivér. „Korunk virágzó biznisze? Az e-sport iparág bemutatása”. Információs Társadalom, XVIII. évf., 1. szám, 2018, 66-92.old. DOI: https://doi.org/10.22503/inftars. XVIII.2018.1.5

Szani Ferenc, és Merkovity Norbert. „Javaslat egy közép-kelet-európai képzési piac kialakítására”. Információs Társadalom, XIV. évf., 1. szám, 2014, 91-108.old.

DOI: https://doi.org/10.22503/inftars.XIV.2014.1.5

Székely Iván. „Jog ahhoz, hogy elfelejtsenek és töröljenek”. Információs Társadalom, XIII. évf., 3. szám, 2013, 7-96.old. DOI: https://doi.org/10.22503/inftars.XIII.2013.3-4.1

Székely Levente. „Egy lépéssel elõrébb a digitális tudományos világban: szakmai konferencia a publikációk elektronikus hozzáférhetõségérõl”. Információs Társadalom, VII. évf., 1. szám, 2007, 114-20.old. DOI: https://doi.org/10.22503/inftars.VII.2007.1.11

Székely Levente. „Győztes vesztesek - az információs társadalom ifjúsága”. Információs Társadalom, XVII. évf., 2. szám, 2017, 53-68.old. DOI: https://doi.org/10.22503/inftars. XVII.2017.2.4

Szűts Zoltán. „Információs társadalom Koreában. Úton a teljes behálózottság felé”. Információs Társadalom, XIV. évf., 3. szám, 2014, 5-18.old. DOI: https://doi.org/10.22503/inftars. XIV.2014.3.1

Szűts Zoltán, és Yoo Jinil. „A kiterjesztett valóság térhódítása”. Információs Társadalom, XIII. évf., 2. szám, 2013, 58-67.old. DOI: https://doi.org/10.22503/inftars.XIII.2013.2.4

Szűts Zoltán, és Yoo Jinil. „Big Data, az információs társadalom új paradigmája”. Informacios Tarsadalom, XVI. évf., 1. szám, 2016, 8-28.old.

https://doi.org/10.22503/inftars.XVI.2016.1.1

Szűts Zoltán, és Yoo Jinil. „A chatbotok jelensége, taxonómiája, felhasználási területei, erősségei és kihívásai”. Információs Társadalom, XVIII. évf., 2. szám, 2018, 41-45.old. https://doi.org/10.22503/inftars.XVIII.2018.2.3

Tamás Pál. „Értelmiségi szereprepedések”. Információs Társadalom, VIII. évf., 4. szám, 2008, 29-32.old. DOI: https://doi.org/10.22503/inftars.VIII.2008.4.7

Tóth Zsolt, és István Bessenyei. „A konstruktivista oktatás környezete és a Moodle”. Információs Társadalom, VIII. évf., 3. szám, 2008, 41-50.old. DOI: https://doi.org/10.22503/inftars. VIII.2008.3.4

Ughy Márton. „A blog hatása a politikai kommunikációra egy fontos politikai blog tükrében”. Információs Társadalom, VII. évf., 3. szám, 2007, 102-14.old. DOI: https://doi.org/10.22503/ inftars.VII.2007.3.6

Vári László. „Szabadság határokkal, avagy európai útmutató a szólásszabadság jogszerű gyakorlásához”. Információs Társadalom, 18. évf., március, 2019, 25.old. https://doi. org/10.22503/inftars.XVIII.2018.3-4.2 
Vida Kinga. „Az idős generáció és az infokommunikáció kapcsolata az idősek nappali ellátásában”. Információs Társadalom, XX. évf., 3. szám, 2020, 71-91.old. http://dx.doi. org/10.22503/inftars.XX.2020.3.5

Vilmányi Márton, és Eszter Révészné Kocsis. „Dinamikus kapcsolati képességek modellezése szervezetközi együttműködések során”. Információs Társadalom, XII. évf., 1. szám, 2012, 80-95.old. https://doi.org/10.22503/inftars.XII.2012.1.4

William, McDougall. „Csoporttudat”. Információs Társadalom, VIII. évf., 4. szám, 2008, 46-54. old. DOI: https://doi.org/10.22503/inftars.VIII.2008.4.10

Z. Karvalics László. „A szociálpolitika megváltozó kontextusai az információs társadalomban”. Információs Társadalom, VI. évf., 2. szám, 2006, 10-14.old. DOI: https://doi.org/10.22503/ inftars.VI.2006.2.2

\section{Irodalom}

Barna, Ildikó, és Árpád Knap. „Antisemitism in Contemporary Hungary: Exploring Topics of Antisemitism in the Far-Right Media Using Natural Language Processing”. Theo-Web, 18. évf., 1. szám, 2019, 75-92.old. https://doi.org/10.23770/TW0087

Bastian, Mathieu, Sebastien Heymann, és Mathieu Jacomy. „Gephi: An Open Source Software for Exploring and Manipulating Networks". Proceedings of the International AAAI Conference on Web and Social Media, 3. évf., 1. szám, 2009, 2.

Blei, David M., és John D. Lafferty. „Topic models”. In Text mining, 101-24, 2009

Blei, David M., Andrew Y. Ng, és Michael I. Jordan. „Latent Dirichlet Allocation”. Journal of Machine Learning Research, 3. évf., Jan. szám, 2003, 993-1022.old.

Bostock, M., V. Ogievetsky, és J. Heer. „D3 Data-Driven Documents”. IEEE Transactions on Visualization and Computer Graphics, 17. évf., 12. szám, 2011, 2301-9.old. https://doi. org/10.1109/TVCG.2011.185

Castells, Manuel, és Gustavo Cardoso. The network society: From knowledge to policy, 2005

Chuang, Jason, Christopher D. Manning, és Jeffrey Heer. „Termite: Visualization Techniques for Assessing Textual Topic Models”. In Proceedings of the International Working Conference on Advanced Visual Interfaces - AVI '12, 74, 2012. https://doi.org/10.1145/2254556.2254572

Daiber, Joachim, Max Jakob, Chris Hokamp, és Pablo N. Mendes. „Improving Efficiency and Accuracyin MultilingualEntity Extraction”.InProceedingsofthe 9thInternational Conference on Semantic Systems - I-SEMANTICS '13, 121, 2013. https://doi.org/10.1145/2506182.2506198

Jacomy, Mathieu, Sebastien Heymann, Tommaso Venturini, és Mathieu Bastian. „ForceAtlas2, A Continuous Graph Layout Algorithm for Handy Network Visualization”, 22. 2012.

Liddy, Elizabeth. „Natural Language Processing”. Center for Natural Language Processing, 2019.

Lipovský, Jan. é. n. urlextract: Collects and extracts URLs from given text. (verzió 0.14.0). Python, é. n. Elérés 2020. április 27. https://github.com/lipoja/URLExtract

Molnár Pál, Pintér Henriett, és Tóth Edit. „A szakmai együttműködések leképeződése a hazai neveléstudományi folyóiratokban: a társszerzői hálózat”. Magyar Pedagógia, 118. évf., 4. szám, 2018, 327-60.old. https://doi.org/10.17670/MPed.2018.4.327 
Németh Renáta, Katona Eszter Rita, és Kmetty Zoltán. „Az automatizált szövegelemzés perspektívája a társadalomtudományokban”. Szociológiai Szemle, 30. évf., 1. szám, 2020, 44-62.old.

Németh, Renáta, és Júlia Koltai. „Sociological knowledge discovery through text analytics (In Press)”. In Pathways between Social Science and Computational Social Science - Theories, Methods and Interpretations, szerkesztette Tamás Rudas és Gábor Péli, 2020

Orosz György. oroszgy/hunlp. Kotlin, 2017. https://github.com/oroszgy/hunlp

Röder, Michael, Andreas Both, és Alexander Hinneburg. „Exploring the Space of Topic Coherence Measures”. In Proceedings of the Eighth ACM International Conference on Web Search and Data Mining - WSDM '15, 399-408, 2015. https://doi.org/10.1145/2684822.2685324

Sievert, Carson, és Kenneth Shirley. „LDAvis: A method for visualizing and interpreting topics”. In Proceedings of the Workshop on Interactive Language Learning, Visualization, and Interfaces, 63-70, 2014. https://doi.org/10.3115/v1/W14-3110

Travers, Jeffrey, és Stanley Milgram. „An Experimental Study of the Small World Problem”. Sociometry, 32. évf., 4. szám, 1969, 425-43.old. https://doi.org/10.2307/2786545

Tsolakidis, Anastasios, Cleo Sgouropoulou, Effie Papageorgiou, Olivier Terraz, és Georgios Miaoulis. „Co-Authorship Networks in Academic Research Communities: The Role of Network Strength”. In 2012 16th Panhellenic Conference on Informatics, 150-55, 2012. https://doi.org/10.1109/PCi.2012.47

Wasserman, Stanley, és Katherine Faust. Social Network Analysis: Methods and Applications, Structural Analysis in the Social Sciences, 1994. https://doi.org/10.1017/CBO9780511815478 


\section{Melléklet}

\begin{tabular}{|c|c|c|}
\hline Folyóiratszám & Tematikus szám címe & $\begin{array}{c}\text { Elemzett } \\
\text { dokumentumok } \\
\text { száma }\end{array}$ \\
\hline $2002 / 3$ & Evolúció & \multirow{6}{*}{$\begin{array}{l}\text { A lapszám nem } \\
\text { szerepel az } \\
\text { elemzésben }\end{array}$} \\
\hline $2003 / 1$ & Gazdaság & \\
\hline $2003 / 2$ & Oktatás & \\
\hline $2004 / 1$ & Internet & \\
\hline $2004 / 2$ & E-kormányzat & \\
\hline $2005 / 1$ & Civil társadalom & \\
\hline $2005 / 2$ & Privacy & 7 \\
\hline $2006 / 2$ & $\begin{array}{l}\text { Információs Társadalom Szakmai Napok } \\
\text { konferencia-szám }\end{array}$ & 12 \\
\hline $2006 / 3$ & Kutatás-fejlesztés-innováció & 9 \\
\hline $2006 / 4$ & Konzervativizmus az információ korában & 13 \\
\hline $2007 / 1$ & E-közigazgatás & 13 \\
\hline $2007 / 2$ & Doktori kutatások az információs társadalomról & 9 \\
\hline $2007 / 4$ & Az információs társadalom kritikája & 10 \\
\hline $2008 / 1$ & A jövő információs társadalma & 13 \\
\hline $2008 / 2$ & Befogadó információs társadalom & 10 \\
\hline $2008 / 3$ & Hálózat az információs társadalom tanításáért & 12 \\
\hline $2008 / 4$ & Csoporttudat vagy kollektív intelligencia? & 16 \\
\hline $2009 / 1$ & Művészet és információs társadalom & 9 \\
\hline $2009 / 4$ & Idősödő információs társadalom & 8 \\
\hline $2012 / 1$ & $\begin{array}{l}\text { Információs társadalom kutatás a Szegedi } \\
\text { Tudományegyetemen }\end{array}$ & 9 \\
\hline $2012 / 3$ & Oktatás & 7 \\
\hline $2012 / 4$ & Információs technológiák és a fenntarthatóság & 5 \\
\hline $2014 / 1$ & eLearning fejlesztések a közszolgálatokban & 7 \\
\hline $2014 / 4$ & Új technológiák, régi kultúrák & 9 \\
\hline $2015 / 2$ & Információs társadalom és ifjúság & 9 \\
\hline $2015 / 4$ & Mesterséges intelligencia & 6 \\
\hline $2016 / 3$ & Okos városok & 10 \\
\hline $2017 / 1$ & Biztonság és magánélet & 6 \\
\hline $2017 / 2$ & Digitális szegénység & 6 \\
\hline $2018 / 1$ & Videojáték és e-sport & 13 \\
\hline
\end{tabular}

